\title{
El correo electrónico como medio de notificación administrativa en el Derecho Propio de Andalucía ${ }^{1}$
}

\author{
Eduardo Gamero Casado \\ Profesor Titular de Derecho Administrativo \\ Universidad de Huelva
}

\begin{abstract}
SUMARIO: 1.- INTRODUCCIÓN. 2.- EL DERECHO ESTATAL BÁSICO: LA CENTRIFUGACIÓN DEL RÉGIMEN JURÍDICO DE LAS NOTIFICACIONES TELEMÁTICAS Y SUS DESACONSEJABLES CONSECUENCIAS. 3.- EL RÉGIMEN ESPECÍFICO DE LAS NOTIFICACIONES ADMINISTRATIVAS POR CORREO ELECTRÓNICO EN ANDALUCÍA. 3.1.- Encuadre normativo: el Decreto 183/2003, de 24 de junio. 3.2.- Requisitos de orden técnico: la constancia y sus vías de consecución; autenticidad, integridad, sellado de fechas. 3.3.Especialidades de procedimiento. a) La previa elección del medio por el destinatario y el señalamiento de los procedimientos en que será de aplicación. b) Particularidades en el envío del mensaje. c) Reglas específicas en cuanto al acceso: fecha de notificación. d) Incidencias en la notificación por correo electrónico: rechazo tácito, supresión del segundo intento e imposibilidad de acceso al contenido. 3.4.- Notific@: el Sistema de Notificaciones Telemáticas de la Junta de Andalucía. a) Descripción general. b) Altas y bajas en el sistema y en los concretos procedimientos en que opere. c) Gestión de las notificaciones. d) Recapitulación crítica. 4.- NOTIFICACIONES ELECTRÓNICAS AUTONÓMICAS EN ENTORNOS ESPECÍFICOS. 4.1.- La mensajería electrónica en redes intranet y en relaciones de sujeción especial. 4.2.- Notificaciones administrativas remitidas al "correo electrónico del ciudadano" facilitado por la propia Junta de Andalucía. La Orden de la Consejería de Presidencia de 7 de mayo de 2003, sobre correo electrónico del ciudadano. 4.3.- La mensajería electrónica convencional como último y desesperado recurso. 5.- FINAL.
\end{abstract}

\footnotetext{
${ }^{1}$ Trabajo elaborado en el marco del Proyecto de Investigación MCyT SEC2001-3696, sobre "Derecho público de la Sociedad de la Información y el Conocimiento". Mi gratitud a José Manuel Fernández Luque, por haberme insistido en la conveniencia de realizar y publicar este trabajo.
} 


\section{INTRODUCCIÓN}

La notificación es un trámite esencial para la gestión administrativa: la eficacia de todos los actos administrativos que afecten a derechos e intereses legítimos depende de su adecuada realización. Tras la reforma de la Ley 30/1992, de 26 de noviembre, del Régimen Jurídico de las Administraciones Públicas y del Procedimiento Administrativo Común (LRJAP) operada por la Ley 4/1999, de 13 de enero, su trascendencia es aún mayor, por cuanto que la notificación debe practicarse antes del dies ad quem para la producción del silencio administrativo, de tal manera que una notificación defectuosa, o la ausencia total de este trámite, supondría la generación de un acto presunto estimatorio o la desestimación presunta de lo pedido. Todo ello determina la necesidad de apoderar a la Administración con instrumentos eficaces de notificación administrativa.

Máxime, cuando la sociedad actual ha transformado radicalmente sus hábitos domésticos, dificultándose de manera extraordinaria la entrega de notificaciones postales al encontrarse los domicilios desocupados la mayor parte del tiempo. La implantación de las nuevas tecnologías de la sociedad de la información y el conocimiento, y su acceso cada vez más generalizado al común de la población, hacen especialmente deseable la articulación de un régimen jurídico específico que contemple la posibilidad de recibir notificaciones administrativas por correo electrónico, adaptando las determinaciones comunes relativas a los medios de notificación a las particularidades específicas que entraña el empleo de este medio.

Uno de los servicios de telecomunicación más extendido en la actualidad es la mensajería electrónica, que puede operar por diferentes sistemas o redes (SMS, UTMS, redes intranet), pero cuyo medio más frecuente -y el que concretamente nos interesa- es su envío y recepción por Internet (MMS). El legislador común ha percibido la utilidad de su empleo y ha procurado atenderla mediante una nueva reforma de la Ley 30/1992, esta vez operada mediante el siempre dudoso recurso a las leyes de acompañamiento (concretamente, el art.68 de la Ley 24/2001, de 27 de diciembre), articulándose, además, mediante una enmienda planteada en el Senado, y evitándose de este modo toda la cuidadosa batería de controles y cautelas preventivas que deben acompañar la reforma de una Ley medular del ordenamiento jurídico, como a todas luces es la LRJAP2 ${ }^{2}$. La reforma adolece de claras deficiencias y contie-

\footnotetext{
${ }^{2} \mathrm{Si}$ hemos de ser coherentes con la doctrina del Tribunal Supremo (no del Tribunal Constitucional) en esta cuestión, la modificación en examen sería inválida, al haber manifestado que:
} 
ne posiciones muy cuestionables: entre ellas, abre la puerta al desarrollo reglamentario de las notificaciones por correo electrónico por parte de todas las Administraciones públicas, propiciando una desaconsejable diversidad de regímenes jurídicos en esta cuestión sobre la que volveremos más tarde. Ahora tan solo anticipamos el dato, para aclarar que el objeto específico de este trabajo es analizar el concreto régimen jurídico aplicable a las notificaciones por correo electrónico que realice la Administración de la Junta de Andalucía.

Así como el interés que presenta el empleo de este medio de notificación ha dado lugar ya a diversas aportaciones doctrinales ${ }^{3}$, el régimen específico de la notificación por correo electrónico en el Derecho administrativo andaluz no ha sido objeto todavía de análisis pormenorizado. La actualidad de esta materia es tanto mayor, cuanto que la Junta de Andalucía acaba de poner definitivamente en marcha -en abril de 2005- un Sistema de Notificaciones Telemáticas propio, denominado Notific@, análogo al SNTS que presta la Administración del Estado ${ }^{4}$ y con el que pueden practicarse notificaciones telemáticas seguras con constancia fehaciente de su entrega.

\footnotetext{
"Esta Sala considera que la abrupta introducción de una materia en las leyes de acompañamiento que pueda significar una modificación sustancial de las normas que serían susceptibles de ser clasificadas en el concepto atípico de «Derecho codificado» dentro del cual podrían incluirse, en una primera aproximación, las leyes orgánicas, principiales o básicas y que constituyen cabeza de grupo de los distintos sectores del ordenamiento, puede ser susceptible de ser considerada como contraria al principio de seguridad jurídica en el supuesto de que no se advierta la justificación suficiente para introducir en la ley de acompañamiento una modificación legislativa cuya eficacia y certeza está en gran parte subordinada a su consideración en relación con el resto del sistema o subsistema en el cual pretende realizarse y cuyos efectos son susceptibles de proyectarse sobre un sector importante del ordenamiento. De resultar indispensable una modificación de tal naturaleza sería menester que la seguridad jurídica consistente en la garantía de la consistencia del ordenamiento producto del estudio y ajuste sistemático de la modificación y de la debida transparencia de su conocimiento se obtenga mediante técnicas normativas adecuadas que tengan su reflejo en el procedimiento de elaboración y en la sistemática de la norma o normas aprobadas y de los enlaces entre ellas"; cfr. STS (Sala $3^{a}$ ) de 27/1/03, rec.388/2000.
}

3 Vid. GAMERO CASADO, E.: Notificaciones telemáticas. Y otros medios de notificación administrativa en el procedimiento común, Bosch, Barcelona, 2005, págs.105 y sigs.; J. VALERO TORRIJOS: El régimen jurídico de la e-Administración. El uso de medios informáticos y telemáticos en el procedimiento administrativo, Comares, Granada, 2004, págs.107 y sigs.; BAUZÁ MARTORELL, F.J.: Procedimiento administrativo electrónico, Comares, Granada 2002; DÁVILA MURO, J.: "La notificación digital hacia los ciudadanos: características y posibles modelos", $\mathrm{SiC}, \mathrm{n}^{\circ}$.44, 2001; y GAMERO CASADO, E.: "La notificación por correo electrónico tras la Ley 24/2001, de 27 de diciembre", REDA, $\mathrm{n}^{\circ} 116,2002$, págs.501 y sigs.

${ }^{4}$ El SNTS o Sistema de Notificaciones Telemáticas Seguras, ofrecido por el Ministerio de Administraciones Públicas mediante un convenio suscrito con Correos y Telégrafos y al que puede accederse en una sección específica del Portal del Ciudadano, en http://www.notificaciones.administracion.es 


\section{EL DERECHO ESTATAL BÁSICO: LA CENTRIFUGACIÓN DEL RÉGIMEN JURÍDICO DE LAS NOTIFICACIONES TELEMÁTI- CAS Y SUS DESACONSEJABLES CONSECUENCIAS}

El marco de referencia común para las notificaciones por correo electrónico radica en el vigente apartado $3^{\circ}$ del art.59 LRJAP, introducido, como se ha dicho, mediante el art.68 de la Ley 24/2001, y cuyo texto es el siguiente:

"Para que la notificación se practique utilizando medios telemáticos se requerirá
que el interesado haya señalado dicho medio como preferente o consentido ex-
presamente su utilización, identificando además la dirección electrónica corres-
pondiente, que deberá cumplir con los requisitos reglamentariamente estableci-
dos. En estos casos, la notificación se entenderá practicada a todos los efectos le-
gales en el momento en que se produzca el acceso a su contenido en la dirección
electrónica. Cuando, existiendo constancia de la recepción de la notificación en
la dirección electrónica, transcurrieran diez días naturales sin que se acceda a su
contenido, se entenderá que la notificación ha sido rechazada con los efectos pre-
vistos en el siguiente apartado, salvo que de oficio o a instancia del destinatario se
compruebe la imposibilidad técnica o material del acceso".

Este nuevo apartado es un precepto ensimismado, que evidencia un notable autismo normativo y se distancia perceptiblemente del régimen común aplicable al resto de medios de notificaciones administrativas. El texto se relaciona poco con su entorno más inmediato (el propio art.59 LRJAP), y nada en absoluto con otras disposiciones más alejadas sistemáticamente, pero con las que guarda una estrecha conexión material. El legislador parece apartar de este modo al correo electrónico del régimen general de las notificaciones administrativas ${ }^{5}$, y construirle en la propia ley del procedimiento común unas reglas específicas que sólo permitan la aplicación del régimen general cuando sea preciso completar estas concretas previsiones.

\footnotetext{
${ }^{5}$ Es el caso, por ejemplo, del art. 40.2.a) y la Disposición Transitoria Novena de la Ley 11/1998, de 24 de abril, General de Telecomunicaciones (actualmente, art.25 LGTe 2003), y su reglamento de desarrollo; de la Ley 5912003, de 19 de diciembre, de Firma Electrónica; el Real Decreto 263/1996, de 16 de febrero, por el que se regula la utilización de técnicas electrónicas, informáticas y telemáticas por la Administración del Estado; y del Real Decreto 1290/1999, de 27 de julio, que desarrolla el artículo 81 de la Ley 66/1997, en materia de prestación de servicios de seguridad en las comunicaciones de las Administraciones Públicas a través de técnicas y medios electrónicos, informáticos y telemáticos, entre otras disposiciones ciertos requisitos establecidos por la Ley para el resto de medios de notificación6. Por obra de la Ley se rompería así el denominado "principio de intangibilidad de de las garantías del interesado y del procedimiento"? frente al empleo de medios informáticos, electrónicos y telemáticos por las Administraciones públicas.
} 
Con ello, el nuevo apartado $3^{\circ}$ del art.59 LRJAP pretende consentir el empleo de este cauce de notificación con mayor flexibilidad que los restantes, definiéndole un régimen específico que le exima de ciertos requisitos establecidos por la Ley para el resto de medios de notificación ${ }^{6}$. Por obra de la Ley se rompería así el denominado "principio de intangibilidad de de las garantías del interesado y del procedimiento"7 frente al empleo de medios informáticos, electrónicos y telemáticos por las Administraciones públicas.

El aspecto más significativo que plantea el art.59.3 LRJAP a los efectos que ahora nos interesan, es que constituye un precepto hibernado, supeditado al desarrollo reglamentario de los requisitos que deba reunir la "dirección electrónica" del ciudadano a fin de poder practicar notificaciones administrativas por correo electrónico. La Ley no contrae este desarrollo normativo al que emita la Administración del Estado, sino que admite implícitamente que cada

\footnotetext{
${ }^{6}$ Impresión que se encuentra respaldada por la justificación de la enmienda con la que se incluyó en el Senado este precepto en la Ley de acompañamiento; se trata, concretamente, de se trata de la enmienda $n^{\circ}$. 249, de modificación del texto original del Proyecto de Ley, presentada por el Grupo Parlamentario Popular en el Senado, y publicada en el BOCG, Serie 11, $\mathrm{n}^{\circ} .41$ (c), de 30 de noviembre de 2001, cuya justificación era la siguiente: "La implantación, desarrollo y generalización de la utilización de las tecnologías de la información y la comunicación en la actividad administrativa y, especialmente, en las relaciones entre los ciudadanos y las Administraciones constituye un factor estratégico para favorecer una sustancial mejora en la eficacia y calidad de los servicios públicos, un efectivo acercamiento de las Administraciones a los ciudadanos. y por ende, para impulsar la competitividad y el desarrollo económico y social.

El continuo desarrollo de los instrumentos y técnicas electrónicas, informáticas y telemáticas encuentra su reflejo en el ámbito administrativo en acontecimientos como el compromiso de los Estados miembros de la Unión Europea de ofrecer a través de Internet los servicios públicos más relevantes (Programa eEurope); la iniciativa estratégica Info XXI «Una Sociedad de la Información para todos»; o la reciente puesta en servicio de distintos portales, como el «Portal del Ciudadano». Simultáneamente, los sistemas de firma electrónica se encuentran cada vez más desarrollados y difundidos en el ámbito de las relaciones entre ciudadanos y Administraciones públicas.

Resulta, en consecuencia, esencial y prioritario facilitar la utilización de las técnicas de información y comunicación para generar una verdadera «Sociedad de la Información». Con tal fin, es indispensable realizar pequeñas adaptaciones en el régimen jurídico general administrativo que posibiliten y proporcionen cobertura jurídica al uso habitual de los medios electrónicos y telemáticos" (la cursiva es mía).

${ }^{7}$ Este principio se infiere por la doctrina de diversos preceptos, como el art.45 LRJAP y alguno de sus desarrollos reglamentarios (así, el Preámbulo y el art.2 del Real Decreto 263/1996, citado), y se resume en la necesidad de que la incorporación de las nuevas tecnologías a la gestión administrativa no entrañe una pérdida de garantías para los ciudadanos; sobre el particular, vid. DE ASÍS ROIG, A.: "Documento electrónico en la Administración pública", en Ámbito jurídico de las tecnologías de la información, CGPJ, Madrid, 1996, pág. 161; OCHOA MONZÓ, J.: “¿Hacia la ciberadministración...”, op.cit., pág. 157; y BAUZÁ MARTORELL, F.J.: Procedimiento..., op.cit., págs. 49 y sig.
} 
Administración pública lleve a cabo esta tarea conforme a su propio saber y entender. Así lo confirman, de otro lado, las disposiciones estatales dictadas con la cobertura de esta habilitación normativa, concretamente el Real Decreto 209/2003, de 21 de febrero, por el que se regulan los registros y las notificaciones telemáticas, así como la utilización de medios telemáticos para la sustitución de la aportación de certificados por los ciudadanos (RDRNT); y la Orden PRE/1551/2003, de 10 de junio, por la que se desarrolla la Disposición Adicional Primera del RDRNT: estas normas reglamentarias no han sido calificadas como Derecho estatal básico, de tal manera que cada Administración pública podrá establecer un régimen específico en materia de notificaciones telemáticas, como de hecho ya ha sucedido en algún caso, y particularmente en Andalucía, según podremos comprobar oportunamente.

En efecto, cada Administración pública dispone de una habilitación legal incontestable en relación con este desarrollo reglamentario, que le permite decidir unilateralmente las condiciones técnicas en que deba desarrollarse la notificación por correo electrónico. En uso de esta potestad reglamentaria se podrá ser más o menos exigente, definir unos requisitos más estrictos o más flexibles, y el valor probatorio de la documentación resultante (sea electrónica o en soporte papel) estará en relación directa con el grado de rigor que el desarrollo reglamentario exija a la transacción. Esto nos conduce irremediablemente a admitir que meras disposiciones reglamentarias de entes territoriales infraestatales (Comunidades Autónomas, Municipios y Provincias), o incluso de administraciones institucionales, pueden determinar decisivamente el modo en que adquieren eficacia los actos administrativos. Es perfectamente imaginable que dos notificaciones idénticas desde el punto de vista técnico sean válidas en unas Comunidades Autónomas y en otras no, en unos Municipios sí y en otros no; o lo que todavía es más preocupante, puede suceder que un mismo ciudadano esté sometido a regímenes distintos de notificación por correo electrónico según con qué Administración pública se relacione en cada momento, de tal manera que, a pesar de utilizar un mismo servicio de mensajería electrónica, las notificaciones que reciba sean válidas cuando las remita su Ayuntamiento y su Diputación Provincial, pero no cuando lo hagan el Estado o su Comunidad Autónoma, por poner un ejemplo. Y peor aún: si es vecino de un Municipio, pero se relaciona con otros (donde radique su empresa, su segunda residencia, etc.), puede que el régimen jurídico de las notificaciones que reciba sea distinto según cuál sea el Ayuntamiento notificador.

Buena muestra de todo ello es el Derecho propio de Andalucía, pues como se anticipó en la Introducción, la Junta de Andalucía ha puesto en marcha un Sistema de Notificaciones Telemáticas distinto al del Estado, como veremos en su lugar (infra, § 3.4). 
Todo ello muestra plásticamente hasta qué punto se ha fracturado en esta materia la pretendida homogeneidad de régimen jurídico de las Administraciones públicas y del procedimiento administrativo que buscaba el art.149.1.18 $\mathrm{CE}$, provocando un sinsentido que nos hace retroceder sensiblemente en cuanto a los niveles de consecución del principio de seguridad jurídica que venía suponiendo la consolidación constitucional del concepto de procedimiento administrativo común. Para restañar esta brecha, convendría, a mi juicio, que el Estado regulase todos los pormenores concernientes a las notificaciones telemáticas en una norma dictada con invocación del título habilitante que contiene el art.149.1.18 ${ }^{\mathrm{a}} \mathrm{CE}^{8}$, y preferiblemente distinta de la Ley $30 / 1992^{9}$, que en mi opinión, debería reordenarse hacia su función tradicional en esta materia: regular el régimen común de los medios de notificación de los actos administrativos, remitiendo a la legislación sectorial los particularismos de cada medio específico de notificación ${ }^{10}$.

No obstante, la situación actual, como ya se ha expuesto, confiere a todas las Administraciones públicas una habilitación legal expresa para desarrollar reglamentariamente las condiciones en que deban practicarse las notificaciones por correo electrónico; es más, el desarrollo reglamentario específico, a decir de la Ley, es imprescindible para que se puedan cursar tales notificaciones: el art.59.3 LRJAP no sólo es un título habilitante de la competencia normativa, sino un mandato de inesquivable cumplimiento si la Administración pública en cuestión desea utilizar servicios de mensajería electrónica para practicar notificaciones administrativas. Andalucía ya ha activado su competencia normativa en la materia, y lo que haremos en adelante es analizar de qué manera lo ha hecho.

\section{EL RÉGIMEN ESPECÍFICO DE LAS NOTIFICACIONES ADMI- NISTRATIVAS POR CORREO ELECTRÓNICO EN ANDALUCÍA}

\subsection{Encuadre normativo: el Decreto 183/2003, de 24 de junio.}

La norma de cabecera en la materia objeto de análisis es el Decreto $183 / 2003$, de 24 de junio (BOJA no $¹ 34$, de 15 de julio), por el que se regula

\footnotetext{
${ }^{8}$ Es también la opinión de V ALERO TORRIJOS, J.: El régimen..., op. cit., pág. 130.

${ }^{9}$ Por ejemplo, la Ley General de Telecomunicaciones, citada; la Ley 34/2002, de 11 de julio, de Servicios de la Sociedad de la Información y de Comercio Electrónico, o incluso la Ley de Firma Electrónica, citada.

${ }^{10}$ Como viene sucediendo, por ejemplo, con la Ley 24/1998, de 13 de julio, del Servicio Postal Universal, en relación con las notificaciones postales.
} 
la información y atención al ciudadano y la tramitación de procedimientos administrativos por medios electrónicos (al que nos referiremos con el acrónimo DPAE, abreviación de la expresión "Decreto de Procedimientos Administrativos Electrónicos”). Aunque toda esta disposición resulte de nuestro interés, centramos la atención sobre dos artículos fundamentales.

En primer término, el art.15 DPAE dispone:

Artículo 15. Notificaciones mediante medios electrónicos o informáticos.

1. Para que las notificaciones administrativas que resulten de la aplicación de las actuaciones contempladas en este Decreto puedan llevarse a cabo mediante medios o soportes informáticos y electrónicos, de conformidad con lo previsto en el apartado 3 del artículo 59 de la Ley 30/1992, de 26 de noviembre, de Régimen Jurídico de las Administraciones Públicas y del Procedimiento Administrativo Común, será preciso que el interesado haya señalado o consentido expresamente dicho medio de notificación como preferente mediante la identificación de una dirección electrónica al efecto. Dicha manifestación podrá producirse tanto en el momento de iniciación del procedimiento como en cualquier otra fase de tramitación del mismo. Asimismo, el interesado podrá, en cualquier momento, revocar su consentimiento para que las notificaciones dejen de efectuarse por vía electrónica, en cuyo caso deberá comunicarlo así al órgano competente e indicar una nueva dirección donde practicar las notificaciones.

2. La notificación telemática se entenderá practicada a todos los efectos legales en el momento en que se produzca el acceso a su contenido en la dirección electrónica, de modo que pueda comprobarse fehacientemente por el remitente tal acceso. Cuando, existiendo constancia de la recepción de la notificación en la dirección electrónica señalada, transcurrieran diez días naturales sin que el destinatario acceda a su contenido, se entenderá que la notificación ha sido rechazada con los efectos previstos en el apartado 4 del artículo 59 de la Ley 30/1992, de 26 de noviembre, de Régimen Jurídico de las Administraciones Públicas y del Procedimiento Administrativo Común, salvo que de oficio o a instancias del destinatario se compruebe la imposibilidad técnica o material del acceso.

En principio, se diría que el régimen específico de la materia en Andalucía no es verdaderamente tal, pues la disposición en examen revela un claro mimetismo respecto del art.59.3 LRJAP, del que trae causa; y aunque pudiera pensarse que este orden de cosas es adecuado, por cuanto que supondría una homogeneidad de facto en el régimen jurídico de la notificación por correo electrónico que evita la fragmentación a que el Derecho estatal permite conducir, realmente no sucede así, pues este conciso mandato normativo deja sin respuesta un sinfín de interrogantes que circundan la práctica de la notificación por correo electrónico. 
En cualquier caso, ese precepto no puede leerse aisladamente del resto del Decreto, y en particular resulta preciso interpretarlo a la luz del art.12 DPAE, que a pesar de su extensión conviene transcribir porque lo invocaremos a menudo; este último dice:

Artículo 12. Requisitos del sistema.

1. La transmisión y recepción de información en red o de documentos electrónicos entre los órganos, unidades y entidades a los que se refiere el artículo $1 \mathrm{o}$ entre éstos y los ciudadanos u otras Administraciones Públicas podrá realizarse a través de los medios y soportes electrónicos a los que se refiere este Decreto siempre que se garantice, en todo caso, el cumplimiento de los siguientes requisitos:

a) La garantía de la disponibilidad y acceso de los referidos medios y soportes y de las aplicaciones informáticas en las condiciones que en cada caso se establezcan.

b) La compatibilidad técnica de los medios, aplicaciones y soportes utilizados por el receptor y el destinatario; $y$,

c) La existencia de medidas de seguridad que eviten el que se intercepten y alteren las comunicaciones, así como los accesos no autorizados.

2. Cuando la relación que se establezca consista en la solicitud de información personalizada a los órganos, unidades y entidades a los que se refiere el artículo 1 sobre documentos y datos que no hayan sido previamente puestos a disposición del público se exigirá, además:

a) Que exista constancia de la transmisión y recepción de la comunicación.

b) Que se identifique fidedignamente al remitente y destinatario de la comunicación.

3. Cuando los medios, documentos y soportes electrónicos a los que se refiere el Decreto vayan a ser utilizados en las relaciones jurídico-administrativas que contempla esta disposición y, concretamente, en las comunicaciones entre el interesado y los órganos, unidades y entidades a los que se refiere el artículo 1 que se deban producir en la tramitación de procedimientos administrativos a través de redes de telecomunicación, se exigirá, además de todo lo anterior:

a) Que el destinatario y el remitente utilicen una firma electrónica avanzada basada en un certificado reconocido y producida por un dispositivo seguro de creación de firma;

b) Que dicha firma se acompañe de un dispositivo o servicio de consignación de fecha y hora que permita acreditar el momento exacto en el que la comunicación se produce y que, a su vez, permita evitar el rechazo de dicha comunicación por el remitente o el destinatario.

4. La Administración velará para que el funcionamiento de los sistemas se realice de acuerdo a unas políticas adecuadas de seguridad, autenticación, de firma electrónica, emisión de sellos de tiempo y recibos electrónicos. Igualmente, los servidores informáticos funcionarán bajo el uso de un certificado de componente emi- 
tido por un proveedor de servicios de certificación electrónica habilitado de conformidad con el Real Decreto-ley 14/1999, sobre Firma Electrónica ${ }^{11}$.

Como se observa, la importancia de este precepto es decisiva, pues establece una serie de requisitos imperativos cuando se trata de cursar notificaciones administrativas por correo electrónico. Sus apartados 1 a 3 suponen una progresiva acumulación de exigencias que resultan todas ellas predicables de las notificaciones por correo electrónico, con la sola excepción de las que se produzcan internamente, esto es, en la red intranet corporativa de la propia Junta de Andalucía. No obstante, a estos efectos el apdo. 3 absorbe en su contenido las exigencias dimanantes del apdo. 2, añadiendo además otros nuevos, por lo que circunscribiremos nuestro análisis al primero de ellos.

Ahora bien, el diseño del art.12 DPAE resulta excesivamente abstracto, quizá porque se concibe como un régimen genérico aplicable a todo tipo de comunicaciones telemáticas y no sólo a las notificaciones por correo electrónico. El problema reside en hacer descender a lo concreto esta panorámica general, y articular el modo en el que opera la exigencia de esta batería de requisitos con ocasión de la tramitación de un procedimiento administrativo singular, cuando el ciudadano pretenda ser notificado en el mismo por correo electrónico, o cuando declare su voluntad de servirse de este medio en toda una categoría de procedimientos.

En este sentido, los arts.12 y 15 DPAE no casan bien entre sí. Interpretados armónicamente, debe suponerse que cuando el ciudadano decida ser notificado por correo electrónico habrán de garantizarse, entre otros extremos, la compatibilidad técnica de los medios, aplicaciones y soportes utilizados por el emisor y el destinatario, la existencia de medidas de seguridad que eviten que se intercepten y alteren las comunicaciones, así como los accesos no autorizados y el resto de exigencias que menudea el art.12; pero el art.15 no establece un procedimiento en cuya virtud la Administración de la Junta de Andalucía proceda a verificar todos estos extremos antes de reconocer el derecho del ciudadano a ser notificado por correo electrónico, y parece proclamar ese derecho del ciudadano con carácter previo y absoluto, lo que resulta a todas luces inadmisible.

Convendría conciliar los arts.12 y 15 en lo que se refiere a las notificaciones por correo electrónico mediante una disposición normativa subordinada

${ }^{11}$ La remisión debe entenderse realizada actualmente a la Ley 59/2003, de 19 de diciembre, de Firma Electrónica. 
(Orden de la Consejería de Justicia y Administración Pública, promovida por la Dirección General de la Administración Electrónica y Calidad de los Servicios, de la Secretaría General para la Administración Pública), que concrete y aclare el protocolo que deba seguirse para reconocer al ciudadano su derecho a recibir notificaciones mediante un determinado servidor de correo electrónico, así como para tramitar las altas y las bajas en los diferentes procedimientos o incluso durante la tramitación de un procedimiento determinado. Tal disposición de desarrollo no ha llegado a dictarse, aun cuando ya se ha implantado el sistema Notific@, que supone un concreto régimen de selección de procedimientos por parte de los ciudadanos a efectos de recibir notificaciones telemáticas que, por las razones que se verán en su lugar, no puede entenderse como un mecanismo excluyente de otros cauces de notificación por correo electrónico.

\subsection{Requisitos de orden técnico: la constancia y sus vías de consecución; au- tenticidad, integridad, sellado de fechas.}

La consagración de un régimen jurídico específico para las notificaciones por correo electrónico en el art.59.3 LRJAP no exime a la Administración de respetar los requisitos que genéricamente prescribe para todo medio de notificación el apdo.1 del mismo artículo, con arreglo al cual: "Las notificaciones se practicarán por cualquier medio que permita tener constancia de la recepción por el interesado o su representante, así como de la fecha, la identidad y el contenido del acto notificado". Tratándose esencialmente de requisitos de constancia, de la mera lectura del precepto se colige que el problema esencial de todo este asunto es de carácter probatorio: la Administración deberá practicar las notificaciones por un medio que le permita demostrar posteriormente todos los extremos pedidos en la Ley, aunque nos interesa destacar que el Derecho estatal común no exige una constancia fehaciente, sino la mera constancia de los elementos indicados. La complejidad que este asunto entraña es que la prueba de las transacciones telemáticas opera con elementos diferentes de la prueba en soporte papel, si bien esta cuestión presenta tal dificultad que resulta imposible tratarla aquí pormenorizadamente, sin perjuicio de lo que puntualmente podamos decir a colación del resto de la exposición ${ }^{12}$.

\footnotetext{
12 Para el estudio detallado del valor probatorio de los diferentes documentos electrónicos puede verse SANCHÍS CRESPO, C.: La prueba por soportes informáticos, Tirant lo Blanch, Valencia, 1999; del mismo autor, "La prueba por soportes informático s en la LECiv 1/2000", Actualidad Informática Aranzadi, no 36, 2000; BARRERO RODRÍGUEZ, C.: La prueba en el procedimiento administrativo, Aranzadi, Elcano (Navarra), 2003, págs.357 y sigs.; GAETE GONZÁLEZ, E.A.: Instrumento público electrónico, Bosch, Barcelona, 2002, passim; BAUZÁ MARTORELL, F.J.: Procedimiento..., op.
} 
En lo que nos interesa, el principal problema que plantea el intercambio telemático es la inseguridad de la transacción, y especialmente, por lo que se refiere a los requisitos de integridad, autenticidad y constancia de la notificación, puede ocurrir que se altere el mensaje, que se suplante la personalidad del receptor, que su destinatario niegue haberlo recibido, etc. ${ }^{13}$. La técnica supera estos obstáculos ofertando una serie de servicios, que se articulan con técnicas biométricas, criptográficas -cifrado- o mediante claves de acceso ${ }^{14}$. Se encuentra bastante generalizada la opinión de que, para su aptitud como me-

cit., págs. 4 y sigs.; GAMERO CASADO, E.: Notificaciones telemáticas, op. cit., págs. 147 y sigs.; MONTERO AROCA, J., GÓMEZ COLOMER, L., MONTÓN REDONDO, A. y BARONA VI LAR, S.: Derecho jurisdiccional, vol.2, Tirant lo Blanch, Valencia, 2000, págs. 329 y sigs.; CORTÉS DOMÍNGUEZ, v. y MORENO CATENA, V.: La nueva Ley de Enjuiciamiento Civil, Tecnos, Madrid, 2000, págs. 73 y sigs.; LORCA NA V ARRETE, A.M. (dir.) y GUILARTE GUTIÉRREZ, V. (coord.): Comentarios a la nueva Ley de Enjuiciamiento Civil, Lex Nova, Valladolid, 2000, págs. 2025 y sigs.; LLANEZA GONZÁLEZ, P.: Internet y comunicaciones digitales. Régimen legal de las tecnologías de la información y la comunicación, Bosch, Barcelona, 2000, págs. 325 y sigs.; CHA VELI DONET, E.: "La prueba por soportes informáticos: algunos apuntes sobre su régimen procesal antes y después de la nueva LECiv", en DA V ARA RODRÍGUEZ, M.A. (coord.): Encuentros sobre Informática y Derecho 2000/01, Aranzadi, Pamplona, 2001, págs.315 y sigs.; BADENAS CARPIO, J.M.: "Diferencia entre firma electrónica y firma electrónica avanzada", Actualidad Jurídica Aranzadi, nº 526, 2002, págs. 5 y 6; V ALERO TORRIJOS, J.: El régimen..., op. cit., págs. 19 y sigs.; y RAYÓN BALLESTEROS, C.: "Las modernas tecnologías en la nueva Ley de Enjuiciamiento", en la misma obra, págs. 347 y sigs.

13 Vid MAR TÍNEZ NADAL, A.: Comercio electrónico, firma digital y autoridades de certificación, Civitas, Madrid, 1998, págs.33 y sigs.; SANCHÍS CRESPO, C.: La prueba..., op.cit., pág.90; GALINDO, F.: "Firma electrónica e instituciones de confianza: algunas precisiones", La Ley, n.4696, 1998, pág.16. Por su parte, DA V ARA RODRÍGUEZ, M.A.: "El documento electrónico en la vigente Ley de Régimen Jurídico de las Administraciones Públicas y del Procedimiento Administrativo Común”, $R A P$, nO.131, 1993, pág.4 77, reprocha a esta crítica el hecho de que el olvido de estas nuevas técnicas conlleva mayores riesgos sobre la garantía de los ciudadanos que su empleo, al deparar éste mayor rapidez, mayor protección y mayor seguridad en el tratamiento de la información.

${ }^{14}$ Una aproximación a todos estos conceptos desde una perspectiva jurídica en GREWLICH, K.W.: Governance in "Cyberspace". Access and Public Interest in Global Communications, Kluwer Law Int., The Hague/London/Boston, 1999, págs. 171 y sigs.; LLANEZA GONZÁLEZ, P.: Internet y comunicaciones digitales. Régimen legal de las tecnologías de la información y la comunicación, Bosch, Barcelona, 2000, págs. 295 y sigs.; BERTRAND, A. y PIETTE-COUDOL, T.: Internet et le droit, PUF, Paris, 1999, págs.90 y sigs.; BARRIUSO RUIZ, C.: La contratación electrónica, Dykinson, Madrid, 1998, págs.223 y sigs.; MARTÍNEZ NADAL, A.: Comercio electrónico, firma digital y autoridades de certificación, Civitas, Madrid, 1998, págs.37 y sigs.; y DÁ VILA MURO, J.; MORANT RAMÓN, J.L.; y SANCHO RODRÍGUEZ, J.: "Autoridades de certificación y confianza digital", en Encuentros sobre Informática y Derecho. 1997-98, Aranzadi, Pamplona, 1998, págs.165 y sigs. También resulta ilustrativa la consulta de AA.VV.: Criterios de seguridad, normalización y conservación de las aplicaciones utilizadas para el ejercicio de potestades, Consejo Superior de Informática y para el Impulso de la Administración Electrónica-Ministerio de Administraciones Públicas, Madrid, 2004, págs.30 y sigs. 
dio seguro de intercambio telemático, un determinado servicio debe reunir las siguientes características ${ }^{15}$ :

- Autenticación: garantiza la identidad del emisor y del receptor.

- Integridad: asegura que el documento llega íntegro a su destino, sin manipulaciones intermedias y sin pérdida de partes de su contenido.

- No rechazo o no repudio en origen: impide que el remitente pueda negar el envío de un mensaje después de haberlo remitido.

- No rechazo o no repudio en destino: impide que el receptor pueda negar la recepción de un mensaje después de haberlo recibido.

- Confidencialidad: preserva el secreto de la comunicación.

El correo electrónico tradicional -el que ofrece con carácter general cualquier empresa prestadora del servicio-, adolece de graves limitaciones en punto a satisfacer estas exigencias, reparos que VALERO resume en los siguientes:

a) La necesaria intermediación de terceros -empresas prestadoras de servicios de mensajería electrónica- en el proceso de notificación, siendo habitual que los servicios de entrada y salida se realicen por prestadores distintos, y circulando además el mensaje por redes abiertas -sin que resulten predecibles los nodos que atravesará-, lo que suscita dudas sobre el momento en que se entiende culminada la notificación.

b) El hecho de que las empresas prestadoras de tales servicios suelen ser privadas, lo que priva a sus declaraciones del carácter probatorio reforzado propio de los documentos públicos administrativos.

c) Los sistemas de correo electrónico que se ofrecen a los internautas son de calidad y características heterogéneas, pudiendo tener muy limitada su capacidad, lo que puede entrañar el rechazo de la notificación por el propio servidor de correo entrante sin que llegue nunca a depositarse en el buzón del destinatario.

d) La eventual ubicación de los servidores de correo fuera del territorio nacional.

e) Las carencias técnicas del servidor a efectos de verificar la firma electrónica del remitente, por lo que no se satisfarían las garantías de autenticidad en origen del envío.

El modo de sortear todos estos reparos es mediante la imposición de una serie de características técnicas a la notificación electrónica. El Decreto 183/2003 se sirve de dos instrumentos principales, contenidos en el art.12.3:

\footnotetext{
15 Vid., por ejemplo, LOMASCOLO SZITTY A Y, R.: "Aspectos técnicos de la firma electrónica”, en AA.VV.: Firma digital y Administraciones Públicas, INAP, Madrid, 2003, pág.59.
} 
a) Que el destinatario y el remitente utilicen una firma electrónica avanzada basada en un certificado reconocido y producida por un dispositivo seguro de creación de firma; y b) Que dicha firma se acompañe de un dispositivo o servicio de consignación de fecha y hora que permita acreditar el momento exacto en el que la comunicación se produce y que, a su vez, permita evitar el rechazo de dicha comunicación por el remitente o el destinatario.

El empleo de una firma electrónica reconocida -como sería calificada el concreto tipo de firma que contempla este precepto conforme a la taxonomía que inauguró la LFE de 2003, posterior al Decreto- introduce un elevado grado de seguridad en las transacciones telemáticas efectuadas en redes abiertas como Internet ${ }^{16}$. A estas características técnicas responde el certificado digital clase 2CA, o Número de Referencia Completo (NRC), un certificado digital basado en criptografía asimétrica que facilita gratuitamente la Fábrica Nacional de Moneda y Timbre (FNMT) y cuyo origen se sitúa en el art.81 de la Ley 66/1997, de 30 de diciembre, de Medidas Fiscales, Administrativas y del Orden Social, precepto que habilita a la FNMT para la prestación de servicios de certificación a la Administración General del Estado y al resto de Administraciones públicas con las que se suscriban los correspondientes convenios, como ha sucedido con la Junta de Andalucía, en cuyas dependencias se puede obtener ${ }^{17}$. En términos más coloquiales, se trata de la firma digital con la que la

\footnotetext{
${ }^{16}$ Sobre la firma electrónica y sus diferentes modalidades puede verse, especialmente, AA.VV.: Firma digital y Administraciones Públicas, INAP, Madrid, 2003,passim; MARTÍNEZ NADAL, A.: La Ley de Firma Electrónica, Civitas, Madrid, 2001; BAUZÁ MARTORELL, F.J.: Procedimiento..., op.cit., págs. 25 y sigs.; y GAMERO CASADO, E.: Notificaciones telemáticas, op.cit., págs.123 y sigs. Podemos definir a la firma electrónica reconocida como aquella que:

1) Permite identificar al firmante y detectar cualquier cambio ulterior de los datos firmados, estando vinculada al firmante y a los datos a que se refiere de manera única, y habiendo sido creada por medios que el firmante puede mantener bajo su exclusivo control (requisitos de la firma electrónica avanzada).

2) Se ha generado mediante tecnologías calificadas como "dispositivo seguro de creación de firma”, esto es, que reúnen los requisitos técnicos señalados en el art.24.3 LFE.

3) Opera provista de un certificado electrónico, es decir, un servicio de seguridad expedido a su vez mediante firma electrónica, y que presta una entidad distinta del emisor y del receptor, vinculando los datos de verificación de firma a un firmante y confirmando su identidad (art.6.1 LFE).

4) Siempre que dicho certificado electrónico haya sido emitido por una entidad previamente reconocida como prestadora de servicios de certificación por otra entidad distinta, que a su vez ha sido acreditada con anterioridad, mediante instrumentos propios del sistema de calidad industrial.

${ }^{17}$ La información relativa a como seguir el procedimiento de obtención de esta firma digital reconocida aparece también expuesta en el portal http://www.andaluciaiunta.es: activando el hipervínculo a la opción "Administración electrónica" se abre una página que, entre otras prestaciones, incluye un enlace relativo a la firma electrónica y a cómo obtenerla.
} 
Agencia Estatal de la Administración Tributaria viene operando desde hace años para admitir la presentación telemática de declaraciones tributarias: ese mismo certificado digital, que cabe pedir por diferentes medios a la Administración del Estado ${ }^{18}$, es el que también puede obtenerse gratuitamente a través de la Administración de la Junta de Andalucía, y su reconocimiento es indistinto y simultáneo por la Administración del Estado (general o institucional) y la de la Junta de Andalucía, en virtud del correspondiente convenio ${ }^{19}$, así como por el resto de Administraciones públicas que se hayan adherido al mismo.

En cualquier caso, debe quedar claro que el DPAE, fiel al principio de neutralidad tecnológica, no impone que sea necesariamente el certificado digital de la FNMT el que opere como herramienta de seguridad y autenticidad en la transacción telemática, siendo suficiente el uso de cualquier firma digital avanzada basada en un certificado reconocido -art.12.3 a) DPAE-, o conforme a la terminología vigente, cualquier firma digital reconocida. Sin embargo, tanto la Administración del Estado como la Junta de Andalucía han impuesto precisamente este concreto certificado digital en sus respectivos sistemas de notificación electrónica (SNTS y Notific@, respectivamente), lo que resulta dudosamente compatible con la libre prestación de servicios de seguridad electrónica que establecen las leyes generales en la materia ${ }^{20}$.

Con la imposición del empleo de una firma digital reconocida tanto por parte de la Administración notificadora como del receptor del mensaje, se introduce en el intercambio telemático a un tercero de confianza (Third trust party) que actúa a modo de notaría digital, consiguiéndose una trilogía de estándares de seguridad sumamente apreciada en el sector tecnológico ${ }^{21}$ :

\footnotetext{
${ }^{18}$ Puede consultarse toda la información al respecto en la URL http://www.cert.fnmt.es/.específicamente dedicada a este certificado digital.

19 Cuyo texto completo se encuentra accesible en http://ws024.iuntadeandalucia.es/plutonDescargasl7 248 convenio- fnmt-junta andalucia.pdf

${ }^{20}$ Vid. GAMERO CASADO, E.: Notificaciones telemáticas, op.cit., págs.141 y sigs.

${ }^{21}$ Es opinión generalizada; vid., por todos, MARTÍNEZ NADAL, A.: La Ley..., op.cit., págs.54 y sigs.; V ALERO TORRIJOS, J.: El régimen..., op.cit., pág.143; POULLET, Y.: "Some considerations on Cyberspace Law", en FUENTES-CAMACHO, T. (ed.): The/international Dimensions ofCyberspace Law, UNESCO-Ashgate, Burlington, 2000, págs.150 y sigs.; y FERNÁNDEZ FERNÁNDEZ, J.J. e CASTILLO V ÁZQUEZ, LC.: Manual de las notificaciones administrativas, Civitas, Madrid, 2004, págs. 438 y Sigs..
} 
- La autenticidad en origen y en destino: se asegura que el emisor y el receptor son verdaderamente quienes dicen ser.

- Integridad: garantiza que el documento electrónico no ha sido manipulado desde que se envía por el emisor hasta que se recibe por el destinatario.

- No rechazo o no repudio: impide que el receptor pueda rechazar o niegue haber recibido el envío una vez realizado.

El único reparo que entraña el empleo de la firma electrónica es su escindibilidad, es decir, el hecho de que puede cederse o ser usurpada por un tercero (enmascaramiento), llegando a utilizarse sin intervención alguna de su titular, a diferencia de la firma manuscrita, que obra como sello personalísimo de complicada falsificación ${ }^{22}$. Esto plantea serios problemas en punto a garantizar de manera absoluta la identidad del suscriptor del acto administrativo (emisor del mensaje), así como del destinatario, al menos mientras que la firma electrónica no se apoye en mecanismos biométricos de refuerzo (huella dactilar, iris de los ojos...) asociados a su empleo, que aseguren incontrovertiblemente su uso por el titular de la misma ${ }^{23}$. Sin embargo, como sostiene BARRIUSO, las claves personales garantizan la identidad en la comunicación telemática, y por ello su cesión por el titular le hace responsable de todas las consecuencias que puedan derivarse de la negligencia en su custodia y secreto $^{24}$. En la misma línea, y aún salvando las distancias, el art.2.2.3 del Anexo de la Orden de la Consejería de la Presidencia de 7 de mayo de 2003, por la que se establecen las condiciones para el uso del Correo Electrónico del Ciudadano, dispone "El usuario deberá custodiar y hacer un uso diligente de su contraseña, cuya confidencialidad es de su exclusiva responsabilidad. En caso de pérdida o robo de la misma deberá comunicarlo a la Administración de la Jun-

${ }^{22}$ El problema preocupa especialmente a BAUZA MARTORELL, F.J.: Procedimiento..., op.cit., págs.65 y 183 y sigs.; y TORRES LÓPEZ, M.A.: "El documento electrónico en las relaciones jurídico-administrativas: especial referencia a los actos de comunicación”, $R V A P, \mathrm{n}^{\circ} 55,1999$, pág. 258.

${ }^{23}$ No es un deseo irrealizable: el DNI digital que facilitará gratuitamente el Ministerio del Interior dispondrá de estas tecnologías.

${ }^{24}$ Según afirma el autor: "Hemos de concienciarnos que la cesión de estas claves equivale a ceder nuestra identidad. Si no se puede garantizar el secreto de las claves y códigos el sistema no es válido. Las claves pertenecen exclusivamente a la persona a la que se conceden (titular), por lo que tienen el carácter de personales e intransferibles. Su vulneración por el titular, le hará responsable de todas las consecuencias que por su negligencia en su custodia y secreto, puedan corresponder"; cfr. BARRIUSO RUIZ, C.: La contratación electrónica, op.cit., pág. 51. 
ta de Andalucía”: un precepto que no es de estricta aplicación a la materia en examen, pero que contribuye a confirmar la afirmación de base que hemos realizado, pues lo propio cabe decir respecto de la cesión de un certificado digital, que potencialmente comporta consecuencias tanto o más graves que entregar a alguien un folio firmado en blanco. En este mismo sentido, la Directiva 1999/93/CE del Parlamento Europeo y del Consejo, de 13 de diciembre de 1999, por la que se establece un marco comunitario para la firma electrónica, y la Ley 59/2003, de Firma Electrónica, responsabilizan de la custodia de los certificados digitales a sus titulares, y presumen la validez de los documentos firmados con ellos; en particular, el art.3.4 LFE dispone que "La firma electrónica reconocida tendrá respecto de los datos consignados en forma electrónica el mismo valor que la firma manuscrita en relación con los consignados en papel”, beneficiándolos de una presunción que dispone además de medios específicos de refutación ${ }^{25}$. Es un tema sin duda apasionante, sobre el que por desgracia no podemos detenernos, remitiéndonos sin más a la bibliografía anteriormente citada -al comienzo de este apartado- en relación con el valor probatorio de los documentos electrónicos.

Más complicado de atender resulta el requisito del sellado de fechas, pedido por el art.12.3 b) DPAE, porque constituye un servicio añadido de telecomunicación que pocos operadores tecnológicos prestan a día de hoy. Es sumamente difícil lograr que un proveedor comercial de servicios de Internet ofrezca a los usuarios esta prestación, y en las aplicaciones usuales es relativamente fácil manipular la fecha de recepción de los mensajes. Este problema puede resolverse cuando el mensaje se entrega en un buzón situado en la galaxia organizativa del emisor, esto es, en una red Intranet cuyos nodos controle el propio emisor del mensaje, de tal manera que las trazas del envío permiten acreditar la fecha de entrega mediante la declaración del administrador del sistema. Pero en redes abiertas, como Internet, el mensaje atraviesa una serie de nodos sucesivos cuya singladura resulta además impredecible, siendo

\footnotetext{
${ }^{25} \mathrm{El}$ art.3.8 LFE dispone: "El soporte en que se hallen los datos firmados electrónicamente será admisible como prueba documental en juicio. Si se impugnare la autenticidad de la firma electrónica reconocida, con la que se hayan firmado los datos incorporados al documento electrónico, se procederá a comprobar que por el prestador de servicios de certificación, que expide los certificados electrónicos, se cumplen todos los requisitos establecidos en la Ley en cuanto a la garantía de los servicios que presta en la comprobación de la eficacia de la firma electrónica, y en especial, las obligaciones de garantizar la confidencialidad del proceso así como la autenticidad, conservación e integridad de la información generada y la identidad de los firmantes. Si se impugna la autenticidad de la firma electrónica avanzada, con la que se hayan firmado los datos incorporados al documento electrónico, se estará a lo establecido en el apartado 2 del artículo 326 de la Ley de Enjuiciamiento Civil".
} 
habitual que no se encuentren bajo el poder directivo del emisor, lo que hace materialmente imposible acreditar la recepción del mensaje en el buzón del destinatario, o que éste lo haya descargado en un equipo terminal (ordenador personal). Más adelante $(\$ 4)$ nos ocuparemos nuevamente de este asunto.

\section{3.- Especialidades de procedimiento.}

a) La previa elección del medio por el destinatario y el señalamiento de los procedimientos en que será de aplicación.

Tanto el art.59.3 LRJAP, como el art.15 DPAE, disponen que el ciudadano habrá debido indicar este medio como preferente para que puedan practicarse notificaciones por correo electrónico. No se trata de un asunto menor, pues existen gran cantidad de inconvenientes que impiden reconocer la posibilidad de que el ciudadano sencillamente declare en el escrito de iniciación, o en cualquier otro posterior, que desea ser notificado por correo electrónico: en primer lugar, puede que sus dispositivos y sistemas no satisfagan los requisitos mínimos de seguridad dispuestos por el art.12, apdos. 2 y 3 RPAE; y en segundo término, puede que las aplicaciones informáticas -los programas de procesamiento de texto, correo electrónico, u otros- utilizadas por la Administración para generar el mensaje y por el ciudadano para recibirlo no sean compatibles entre sí. El art.12.1 b) DPAE exige que "para la transmisión o recepción de información en red (...) se garantice, en todo caso (...) la compatibilidad técnica de los medios, aplicaciones y soportes utilizados por el emisor y el destinatario", pero no determina cómo articular esa garantía, ni tampoco cómo verificar que los equipos y dispositivos del destinatario reúnen las exigencias técnicas en cuestión. Existen al menos dos maneras de solucionar estos problemas.

1) La primera es que la Administración articule un procedimiento previo de verificación del cumplimiento de los requisitos por parte de los dispositivos, aplicaciones y sistemas utilizados por el destinatario. Esto exige que previamente incluso a la verificación se informe a los ciudadanos de las aplicaciones informáticas que se utilizarán para los envíos, teniendo presente el principio de neutralidad tecnológica -expresamente proclamado, por otra parte, en el art.12.1 a) DPAE-, en cuya virtud habrán de ofrecerse diferentes alternativas o garantizar suficientemente la disponibilidad de las aplicaciones necesarias. Así, habrán de poder soportar el servicio al menos dos navegadores de Internet suficientemente implantados en el mercado; dos o más programas de correo electrónico; dos lectores de imágenes en el caso de que vayan a remitirse archivos de este ti- 
po (por ejemplo, por las características de integridad que ofrece el formato pdf, es muy oportuno el envío del documento a notificar mediante un fichero ligado al mensaje que contenga la imagen escaneada del documento convertida a dicho formato); o bien facilitar gratuitamente al ciudadano el software necesario, que habrá de ser compatible con los sistemas operativos más implantados del mercado. También es preciso advertir previamente al usuario los requisitos mínimos de los dispositivos y sistemas que deban soportar dichas aplicaciones: capacidades de memorias, velocidad de proceso de datos, resolución, etc., exigencias que a menudo dependen no sólo del programa utilizado, sino incluso de la versión que concretamente se emplee.

Esta fase previa no aparece regulada en ninguna disposición normativa, lo cual puede crear en los ciudadanos la falsa impresión de que ostentan un derecho absoluto a ser notificados por correo electrónico con el simple requisito (carga, en términos técnico-jurídicos) de declarar este medio de notificación como preferente e indicar su "dirección electrónica"; pero esta hipótesis es inadmisible, porque la eficacia del acto administrativo no puede quedar entregada a la libre disposición del ciudadano, y la notificación puede ser infructuosa en el caso de enviarse sin solventar previamente estas objeciones. Podría pensarse que, cuando el ciudadano solicita a la Administración ser notificado por este medio, conoce las exigencias legales y declara tácitamente satisfacerlas. En tal caso, cualquier problema en la notificación sería imputable a su propia torpeza, sin que pueda alegarlo como motivo de invalidez de posteriores actuaciones administrativas (art.110.3 LRJAP $^{26}$ ). Pero incluso este argumento chirría cuando recordamos que uno de los problemas que puede entrañar la comunicación telemática es la conectividad, esto es, la compatibilidad de las aplicaciones, de modo que la Junta de Andalucía habría de advertir previamente los programas de mensajería electrónica que utilizará y los requisitos mínimos de los sistemas que los soporten, cosa que de momento no nos consta que haya hecho, y este tipo de obstáculos no son imputables al ciudadano sino a la Administración.

Por último, es preciso recordar que difícilmente los proveedores actuales de servicios de Internet ofrecen el sellado de fechas de los intercambios telemáticos, por lo que será muy raro articular envíos en los que quede constancia de la fecha de recepción por el destinatario, salvo que éste envíe un acuse de recibo, naturalmente, pero en tal caso el momento de efi-

\footnotetext{
${ }^{26}$ Sobre el principio nemo auditur turpitudinem aUegans o prohibición de alegar la propia torpeza, y su aplicación al asunto en examen, puede verse ARANA GARCÍA, E.: La alegación de la propia torpeza y su aplicación al Derecho administrativo, Comares, Granada, 2003, págs.65 y sigs.
} 
cacia del acto (y de producción de silencio) quedan entregados a su esfera de decisión, lo que puede desembocar en graves problemas: el más elemental, que el ciudadano no remita acuse de recibo alguno y provoque de ese modo un silencio positivo que le favorezca.

2) La segunda opción, más razonable en términos técnicos por lo que hemos podido comprobar según cuanto llevamos expuesto, es que sea la Administración quien facilite al ciudadano un buzón de correo en el que practicar las notificaciones administrativas, dotando al servidor de los requisitos específicos de seguridad y constancia que piden las normas vigentes, los cuales, añadidos a la firma digital reconocida del ciudadano, permitirían superar limpiamente todas las exigencias que plantea el uso de este medio de notificación. Esta determinación es la que ha adoptado la Administración del Estado, articulándola mediante un convenio de dudosa legalidad -conduce a un monopolio de hecho-, suscrito entre el Ministerio de Administraciones Públicas y Correos y Telégrafos, facilitándose gratuitamente a todo ciudadano que lo solicite un Servicio de Notificaciones Telemáticas Seguras ciertamente admirable ${ }^{27}$. La opción no casa bien con el tenor literal de la LRJAP y del DPAE, conforme a los cuales es el ciudadano quien indica a la Administración cuál es la "dirección electrónica" en la que desea ser notificado, y no la Administración quien obliga al ciudadano a servirse precisamente de la "dirección electrónica" que ella misma le facilita; pero si recordamos las prisas con las que se aprobó la modificación de la Ley 30/1992 (de la que trae causa el texto del DPAE), no nos puede extrañar de que contenga ésta y otras determinaciones difíciles de llevar a la práctica desde el punto de vista tecnológico; al menos, si deseamos que verdaderamente puedan notificarse actos administrativos en entornos de confianza.

Como ya sabemos, la Junta de Andalucía se ha decantado recientemente por esta segunda opción -emulando a la Administración del Estado- mediante la creación de Notific@, esto es, de un sistema propio de notificaciones telemáticas. La decisión es acertada en la medida que el mejor modo de conciliar las exigencias técnicas de los sistemas con el régimen jurídico de las notificaciones telemáticas es mediante la práctica de las notificaciones administrativas empleando un servidor emplazado bajo la órbita directiva de la Junta de Andalucía, a efectos de satisfacer ciertos requisitos normativos (como el sellado

27 Vid. el portal específico de este servicio (asociado al portal del ciudadano) en la URL http://notificaciones.administracion.es; así como GAMERO CASADO, E.: Notificaciones telemáticas, op.cit., págs. 226 y sigs. 
de fechas) difícilmente alcanzables mediante los servicios de mensajería electrónica que ofrecen las empresas comerciales. Lo que ya no parece tan conveniente -lo recordaremos en su lugar- es duplicar los sistemas de notificación electrónica cuando el mismo resultado podría haberse logrado mediante la adhesión de la Junta de Andalucía al SNTS de la Administración del Estado, lo que hubiera sido coherente con el empleo por la Administración autonómica de la firma reconocida generada por la FNMT sin llegar a crear otro certificado digital diferente y exclusivo de Andalucía.

Por otra parte, el art.15.1 DPAE dispone que el interesado podrá manifestar su deseo de ser notificado por este medio tanto en el escrito de iniciación del procedimiento como en cualquier momento posterior; y que asimismo, en cualquier momento podrá revocar su consentimiento. El precepto es muy generoso y consiente al ciudadano un cambio de criterio que puede repercutir dificultades organizativas graves a la Administración, pero es inobjetable desde el punto de vista legal. De otro lado, constriñe las vías de manifestación del ciudadano a las expresamente indicadas, pero parece posible articular una tercera que, de ejercerse voluntariamente, no entrañaría a mi juicio problemas de validez: la declaración previa al procedimiento, que pueda incorporarse por la Administración a un fichero susceptible de registrar altas y bajas generales de solicitudes de notificación electrónica en un catálogo de procedimientos administrativos aptos para admitir este medio de notificación. Esta manifestación previa resultará especialmente útil en procedimientos iniciados de oficio -en los que el ciudadano no podrá indicar el medio de notificación preferente en el escrito de iniciación, por cuanto que éste no emana de su esfera personal, sino de la propia Administración-, facilitando las cosas tanto a la gestión administrativa de los expedientes como al propio ciudadano. Esta es la opción elegida por Notific@, el sistema de notificaciones telemáticas de la Junta de Andalucía.

\section{b) Particularidades en el envío del mensaje.}

El envío de una notificación por correo electrónico debe reunir los requisitos generales que para toda notificación exige el art.58 LRJAP: el texto íntegro del acto, la fecha en que se dictó, el pie de recursos, la firma del titular del órgano administrativo, etc. Pero además, ha de satisfacer los requisitos específicos de seguridad dispuestos por el régimen específico de este medio de notificación. Hay al menos dos maneras de conciliar ambas exigencias.

La primera opción es elaborar el documento en soporte papel, como si se tratara de una notificación convencional, para luego digitalizar su imagen (es- 
canearlo) y efectuar su tratamiento informático mediante un programa que nos ofrezca un fichero final de sólo lectura (como los que se realizan en formato pdf), garantizándose así la no alteración de su contenido. Estas operaciones equivaldrían a fotocopiar el original en papel para enviarlo al receptor, conservando el original del acto administrativo en su expediente y enviando la fotocopia, salvo que en este caso también conservaríamos copia -digital- del acto escaneado. Posteriormente, remitiremos un correo electrónico al interesado, adjuntando el fichero en cuestión, y encriptando el mensaje con la firma electrónica reconocida del emisor. El destinatario, cuando recibe el mensaje, dotado de equipos y aplicaciones compatibles, puede ejecutar el fichero adjunto y conocer el contenido íntegro del acto.

La otra alternativa, menos frecuente todavía pero cada vez más extendida, es la tramitación de todo el procedimiento administrativo en soporte digital. Si en estas circunstancias también la notificación será electrónica, resulta por completo innecesario imprimir el acto administrativo resolutorio: bastará con prepararlo mediante la aplicación informática correspondiente, incluyendo todos los elementos de la notificación (contenido íntegro, fecha, pie de recursos...), y suscribirlo digitalmente con la firma electrónica reconocida del titular del órgano administrativo resolutorio. Una segunda modalidad de este mismo supuesto se daría si el órgano resolutorio y el notificante fueran distintos (por carecer el primero del acceso a las aplicaciones de notificación, por haberse encomendado la función de notificar a un órganos específico distinto del resolutorio...), en cuyo caso el acto administrativo sería firmado digitalmente por el titular del órgano resolutorio, y la notificación (que incluirá, a su vez, el acto resolutorio) sería firmada digitalmente por el órgano notificante.

El empleo de firmas electrónicas en punto a generar los documentos administrativos llega a permitir la automatización integral del procedimiento, siendo perfectamente imaginable el desarrollo de todas sus fases mediante aplicaciones informáticas específicas que desemboquen en la inserción automática de la firma digital en el acto administrativo como fase final de todo el proceso. Esto, a su vez, plantea interesantes cuestiones sobre la teoría general del órgano administrativo y su emisión de voluntad, de las que se ha ocupado VALERO, a quien remitimos para su estudio detallado ${ }^{28}$.

28 Vid V ALERO TORRIJOS, J.: El régimen..., op.cit., págs.26 y sigs. 
c) Reglas específicas en cuanto al acceso: fecha de notificación.

El art.59.3 LRJAP pretende resolver apretadamente todo el rosario de particularidades que resulta preciso regular para atender las especialidades que entraña el empleo del correo electrónico como medio de notificación administrativa. El Derecho autonómico parece haberse contagiado por este mismo afán de concisión, resumiendo todas las patologías y particularismos que eventualmente puede presentar la notificación por correo electrónico en el art.15.2 DPAE, que dispone: "La notificación telemática se entenderá practicada a todos los efectos legales en el momento en que se produzca el acceso a su contenido en la dirección electrónica, de modo que pueda comprobarse fehacientemente por el remitente tal acceso. Cuando, existiendo constancia de la recepción de la notificación en la dirección electrónica señalada, transcurrieran diez días naturales sin que el destinatario acceda a su contenido, se entenderá que la notificación ha sido rechazada con los efectos previstos en el apartado 4 del artículo 59 de la Ley 30/1992, de 26 de noviembre, de Régimen Jurídico de las Administraciones Públicas y del Procedimiento Administrativo Común, salvo que de oficio o a instancias del destinatario se compruebe la imposibilidad técnica o material del acceso". Estas disposiciones construyen una serie de reglas específicas en relación con las incidencias que pueden presentarse en el acceso al contenido de la notificación. Se trata, por tanto, de determinaciones relativas a la eficacia del acto administrativo notificado.

La primera particularidad es la determinación del dies a quo de la notificación, y debe notarse que en este punto difieren el Derecho estatal y el autonómico andaluz. El art.59.3 LRJAP solamente dispone que "La notificación se entenderá practicada a todos los efectos legales en el momento en que se produzca el acceso a su contenido en la dirección electrónica”, a lo que el art.15.2 DPAE añade la siguiente paráfrasis adicional: "de modo que pueda comprobarse fehacientemente por el remitente tal acceso”.

La aparente colisión en este punto entre el Derecho estatal y el autonómico encuentra como telón de fondo la doctrina constitucional acerca de la distribución de competencias en materia de procedimiento administrativo común, contenida, principalmente, en las SSTC 227/1988 y 198/1991, en cuya virtud, la competencia autonómica en materia de procedimiento administrativo se articula en torno a dos ejes: las disposiciones necesarias en materia de autoorganización autonómica (que supone la habilitación del título competencial necesario para dictar las previsiones adjetivas o complementarias en materia de procedimiento que requieran las particularidades organizativas propias de la Comunidad Autónoma), y el criterio de la conexión, esto 
es, la atribución a la Comunidad Autónoma de una competencia sectorial sustantiva, que lleva implícitamente asociada la competencia para aprobar los procedimientos administrativos conforme a los que se ejercerá dicha competencia; en ambos casos, es imperativo para el legislador autonómico respetar las garantías mínimas -comunes- previstas en la LRJAP en beneficio de los ciudadanos.

Es preciso interpretar el art.15.2 DPAE de conformidad con estos postulados constitucionales. Para lograrlo, hemos de considerar, en primer término, que supone una manifestación del título competencial relativo a las particularidades organizativas autonómicas, pues no puede incardinarse en una competencia sustantiva específica, al versar sobre una materia horizontal o transversal, esto es, el procedimiento de notificación de los actos administrativos. Y en segundo lugar, hemos de interpretar su contenido en un sentido que no restrinja o limite las garantías que el régimen del procedimiento administrativo común reconoce al ciudadano. Este segundo aspecto resulta un poco más problemático, pues evidentemente no es lo mismo que se entienda practicada la notificación sólo cuando se produzca el acceso a su contenido, que cuando además de esto, tal acceso pueda comprobarse fehacientemente por el emisor.

Procedamos, en primer término, a concretar qué significa la expresión "que se produzca el acceso a la dirección electrónica". En este sentido, "dirección electrónica" es un concepto de nuevo cuño, alumbrado por la Ley 24/2001, que el art.59.3 LRJAP emplea hasta tres veces, en sentidos semánticos aparentemente distintos, por lo que suscita problemas de interpretación. En primer lugar, cuando el legislador supedita la validez del medio de notificación al hecho de que la "dirección electrónica" satisfaga los requisitos reglamentariamente establecidos: en este caso, hubiera sido mejor decir "el servidor de correo electrónico", porque de la dirección sólo son predicables requisitos de sintaxis, en tanto que sobre el servidor pueden imponerse exigencias de seguridad (como la autenticación en el acceso al buzón, la aplicación de técnicas criptográficas para el envío y recepción de los mensajes o garantías de integridad del contenido) y algunos servicios cualificados (como la expedición de acuses de recibo de los mensajes llegados al servidor y/o descargados desde él a un equipo terminal, o el sello de fechas), que son, entre otros, los que con posterioridad ha exigido el desarrollo reglamentario del precepto, tanto en el Derecho estatal como en el autonómico, según hemos tenido ocasión de comprobar; estas características no resultan predicables de la dirección electrónica en sí misma, pero sí del servidor de correo en el que se hospeda el buzón asociado a la dirección. 
En segundo lugar, la misma expresión es empleada incorrectamente cuando el legislador afirma que la notificación se produce en el momento en que se tiene constancia del acceso a su contenido en la "dirección electrónica": este es el concreto aspecto que ahora nos interesa. Pues bien, la dirección electrónica no es un lugar al que se tenga acceso, lo es el buzón que el servidor pone a disposición del usuario; por ofrecer un ejemplo comparativo, sería igualmente absurdo afirmar que se contesta a una llamada cuando se accede al contenido del número de teléfono. Para interpretar el sentido de la expresión en este caso prefiero cotejarlo con el siguiente.

En tercer lugar, se evidencia un uso incorrecto de la misma expresión cuando la Ley permite entender rechazada la notificación de haber permanecido ésta diez días en la "dirección electrónica", siendo así, nuevamente, que la "dirección electrónica" no puede contener la notificación, al menos en su acepción tradicional, dado que hasta hoy se trata de un mero nomen, de una identidad de destino, y no de un espacio físico (en este caso, electrónico) propiamente dicho.

En los dos últimos casos es donde el texto suscita mayores dificultades de intelección, dado que la inexactitud observada permite articular dos alternativas diferentes de interpretación, según se entienda que el legislador hacía referencia a la disponibilidad del mensaje en el servidor o a su descarga en un equipo terminal por el destinatario: como es sabido, se trata de dos momentos radicalmente distintos que no sólo pueden estar muy separados en el tiempo, sino que, además, son completamente independientes, pudiendo darse el caso de que el destinatario no descargue nunca un mensaje que se encuentra disponible en su servidor ${ }^{29}$.

\footnotetext{
${ }^{29}$ La preocupación que esta duda suscita es mayor cuando se recuerda que existen medios por los que un destinatario puede conocer la llegada de un mensaje a su servidor sin necesidad de descargarlo en un equipo terminal, y por consiguiente, sin que a la Administración le pueda constar que conoce la llegada del mensaje. Esto ocurriría, por ejemplo, de emplear el destinatario algún servicio webmail, que muchos proveedores ponen a disposición de sus clientes, y con cuya utilización el destinatario puede saber que le ha llegado un mensaje y quién se lo remite sin necesidad de descargado en su equipo ni acceder a su contenido. Por ejemplo, RedIris (encuadrada en el CSIC), pone a disposición de todos los usuarios pertenecientes a sus instituciones afiliadas el servicio SAUCE (Servicio de Acceso Universal al Correo Electrónico), cuyo objetivo es que desde cualquier punto conectado a Internet (salas de usuarios en congresos, PC portátil, ciber cafés, etc) sea posible leer y enviar correo electrónico, simplemente utilizando un navegador y sin necesidad de configurar ningún programa específico de correo electrónico (vid. http://www.rediris.es/sauce). Una de las principales utilidades de estos servicios es la de permitir accesos remotos a servidores accesibles únicamente por redes intranet, cuando tales servidores son configurados para rechazar cualquier conexión externa por razones de seguridad, algo cada vez más frecuente en redes bunkerizadas para prevenir ataques hostiles.
} 
Lo razonable será entender que el legislador ha empleado en cada uno de estos casos la expresión "dirección electrónica" en un sentido diferente. En efecto, a mi modo de ver, se debe considerar que la notificación es eficaz cuando el destinatario descargue el mensaje desde su servidor a un equipo terminal (ya sea una computadora, un teléfono fijo o móvil, una agenda electrónica, un televisor, o cualquier otro ${ }^{30}$ ), en tanto que el rechazo implícito operaría cuando la notificación estuviera disponible en el servidor durante diez días sin que el destinatario acceda a su contenido. Esta interpretación es en cierto modo de sentido común, pero en un ámbito tan sensible a la tutela judicial efectiva como la práctica de la notificación no debería tolerarse la ambigüedad a que conduce la imprecisión del apartado en examen ${ }^{31}$.

Retomemos pues el hilo principal de la exposición recordando que se trata de determinar qué consecuencias entraña el hecho de que, en el Derecho propio de Andalucía, a la expresión "la notificación se entenderá practicada a todos los efectos legales en el momento en que se produzca el acceso a su contenido en la dirección electrónica" que figura en el art.59.3 LRJAP se le haya añadido el epílogo "de modo que pueda comprobarse fehacientemente por el remitente tal acceso", que figura en el art.15.2 DPAE. A mi juicio, el hecho de que exista constancia de haberse practicado la notificación no supone realmente una adición al régimen que se desprende rectius del procedimiento ad-

${ }^{30}$ El desarrollo de tecnologías PLC, que permitirán el acceso a Internet por medio de la red eléctrica, como las que Endesa espera ofrecer en breve (actualmente realiza pruebas en Zaragoza, a través de su filial ERZ, ofreciendo una velocidad de conexión de $2 \mathrm{Mbit} / \mathrm{seg}$.), puede revolucionar este mercado y ampliar enormemente el espectro de aparatos terminales susceptibles de ofrecer prestaciones de mensajería electrónica: cualquier equipo eléctrico podría actuar como terminal de correo siempre que reuniese las correspondientes exigencias de hardware y software. Sobre el régimen jurídico de esta nueva tecnología puede verse ZEGARRA V ALDIVIA, D.: "Prestación de servicios de telecomunicaciones a través de redes eléctricas y competencia", RVAP, $\mathrm{n}^{\mathrm{o}} .65,2003$, págs.221 y sigs.

31 Como evidencia el hecho de que el precepto ha sido interpretado diferentemente por otros autores: es el caso de V ALERO TORRIJOS, J.: El régimen..., op.cit., pág. 149, quien considera que, a efectos de entender practicada la notificación por correo electrónico, bastaría con que el interesado accediera a su buzón, sin necesidad de acceder efectivamente al contenido de la notificación (esto es, de descargarse el mensaje electrónico que la contiene). No puedo compartir esta interpretación porque la aplicación del canon literal depara resultados más beneficiosos para el interesado, ya que el art.59.3 LRJAP dispone expresamente que "la notificación se entenderá practicada a todos los efectos legales en el momento en que se produzca el acceso a su contenido en la dirección electrónica”, y a mi juicio, el texto resulta contundentemente expresivo de su significado, pues de otro modo hubiera debido decir "desde el momento en que se produzca el acceso a la dirección electrónica" -o más exactamente, "al buzón de correo electrónico-, lo cual es muy distinto. 
ministrativo común, toda vez que el art.59.1 LRJAP, aplicable a todos los medios de notificación y por tanto también al correo electrónico, impone en todo caso que el medio empleado permita tener constancia de la recepción; en este sentido, el texto adicionado por el art.15.2 DPAE concordaría perfectamente con el Derecho estatal.

De otro lado, y como tuvimos ocasión de destacar anteriormente, el término fehaciente no aparece en el Derecho estatal común relativo a los medios de notificación (art.59.1 LRJAP), que únicamente exige el empleo de un medio que permita la constancia de ciertos extremos, pero no su constancia fehaciente. Este último es un concepto jurídico indeterminado que no aparece definido en ninguna disposición general. El Derecho sectorial lo contiene esporádicamente para reservar al sector público determinados servicios añadidos de telecomunicación, y tal vez en él podamos encontrar orientación para resolver el problema.

El art.25.2 de la Ley 32/2003, de 3 de noviembre, General de Telecomunicaciones (LGTe), dispone: "El Gobierno podrá, asimismo, imponer otras obligaciones de servicio público, previo informe de la Comisión del Mercado de las Telecomunicaciones, motivadas $(\ldots)$ d) Por necesidad de facilitar la disponibilidad de servicios que comporten la acreditación de fehaciencia del contenido del mensaje remitido o de su remisión o recepción". El antecedente normativo inmediato de este precepto era el art.40.2.a) de la Ley 11/1998, de 24 de abril (anterior LGTe), que con mayor pedagogía que el vigente disponía: "Los servicios de télex, los telegráficos y aquellos otros de características similares que comporten acreditación de la fehaciencia del contenido del mensaje remitido o de su remisión o recepción" podrán incluirse en la categoría de servicios obligatorios de telecomunicación ${ }^{32}$.

\footnotetext{
${ }^{32}$ Sobre el particular, vid. MALARET i GARCÍA, E.: “Comentario al artículo 40", en Comentarios a la Ley General de Telecomunicaciones (Ley 11/1998, de 24 de abril), Civitas, Madrid, 1999, págs.299 y sigs.; FERNANDO PABLO, M.M.: Derecho general de las telecomunicaciones, Colex, Madrid, 1998, págs. 139 y sigs. y 205 y sigs.; SOUVIRÓN MORENILLA, J.M.: El proceso de liberalización y la nueva regulación de las telecomunicaciones, Comares, Granada, 1999, págs.204 y sigs.; MONTERO, J.J. y BROKELMANN, H.: Telecomunicaciones y televisión. La nueva regulación en España, Tiranto lo Blanch, Valencia, 1999, págs.383 y sigs.; MOLLINEDO CHOCANO, J.J.: "Los servicios de telecomunicación", en El nuevo marco jurídico de loas telecomunicaciones y de los servicios audiovisuales, CGPJ, Madrid, 1999, pág.194; GIMENO FELIU, J.M.: "Las telecomunicaciones", en BERMEJO VERA, 1. (Ed.): Derecho administrativo. Parte especial, Civitas, Madrid, 1998, págs.1 018 y sig.; CASTELLANO TREVILLA, J.L.: "Servicio universal y los servicios obligatorios en la Ley General de Telecomunicaciones", en Curso de Derecho de las telecomunicaciones, Dykinson-Universidad Rey Juan Carlos, Madrid, 2000, págs.139 y sigs.; ARPÓN DE MENDIVIL, A.: "Obligaciones de servicio público", en Comentarios a la Ley General de Telecomunicaciones, Aranzadi, Pamplona, 1998, págs.453 y sigs.; y CASTEJÓN MARTÍN, L.: "Mercados de telecomunicaciones", en Comentarios a la Ley..., op. u/t. cit., pág. 97.
} 
Estos servicios finales de valor añadido ${ }^{33}$ permiten satisfacer los requisitos de constancia exigidos por la LRJAP en relación con la práctica de las notificaciones. De hecho, su posible configuración como obligaciones de servicio público trae causa justamente de que al permitir la acreditación fehaciente del contenido del mensaje y de su recepción constituyen un cauce idóneo para la práctica de notificaciones que precisen este grado de constancia ${ }^{34}$. Según el art.37 del Real Decreto 1736/1998, de 31 de julio, por el que se aprueba el reglamento de desarrollo del Título III de la LGTe (RSU), tales servicios son el télex, el telégrafo, el burofax, y aquellos otros servicios de características similares que comporten acreditación de la fehaciencia del contenido del mensaje remitido o de su remisión o recepción. Esta redacción, que en su día se apoyó en el art.40.1 LGTe 1998, y actualmente encuentra cobertura legal en el art.25 LGTe, supone el reconocimiento de una habilitación al Gobierno para la declaración de los concretos servicios que merezcan la calificación de obligaciones de servicio público, por lo que la relación del RSU no es excluyente de otros servicios (como la mensajería electrónica) que posteriormente se incluyan en esta categoría ${ }^{35}$. La extraña calificación legal ("obligaciones de servicio público") no parece sino un eufemismo equivalente al servicio público a secas, justificado en la necesidad de garantizar la prestación de estos servicios con independencia de su rentabilidad empresarial ${ }^{36}$.

La Disposición Transitoria Cuarta de la propia Ley establece que "En tanto no se proceda al desarrollo de lo dispuesto en el artículo 25 de esta Ley, la Sociedad Estatal Correos y Telégrafos, S.A., prestará directamente los servicios de télex, telegráficos y otros de características similares, a los que se refiere el

\footnotetext{
${ }^{33}$ Sobre esta categoría en el tema que nos ocupa vid RA VENTÓS. A.: "Servicios de valor añadido: conmutación de datos por paquetes, por circuitos...", en Derecho de las Telecomunicaciones La Ley-Ministerio de Fomento, Madrid, 1997, págs.377 y sigs.

${ }^{34}$ Para FERNANDO PABLO, M.M.: Derecho general..., op.cit., pág.206, la calificación como servicio público se conecta con inequívocas funciones públicas, y en nuestro caso, con la acreditación de la fe pública documental.

${ }^{35}$ En el mismo sentido, MALARET i GARCÍA, E.: "Comentario al art.40", op.cit., págs.304 y sigs. Por ejemplo, el RDLFE no reserva al sector público la prestación del servicio de creación de firma digital, que en principio cumple los requisitos para ser encuadrado en esta categoría.

${ }^{36}$ Vid MALARET i GARCÍA, E.: “Comentario al art.40”, op.cit., pág.302; y FERNANDO PABLO, M.M.: Derecho generaL., op.cit., pág. 139. La noción no es equivalente a la de "obligaciones especiales de operadores de servicios esenciales", sobre la que puede verse FERNÁNDEZ GARCÍA, M.Y: "Las obligaciones especiales de los operadores de los servicios esenciales económicos en red", $R A P, \mathrm{n}^{\circ} .163$, págs. 127 y Sigs.
} 
artículo 25.2 de esta Ley, ajustándose, en su caso, a lo que prevea el reglamento previsto en el apartado 3 de dicho artículo" 37, en lógica correspondencia con el derecho especial que la Ley del Servicio Postal reconoce a la misma Sociedad Estatal para practicar las notificaciones postales. Estos servicios obligatorios de telecomunicación son explotados en régimen de gestión directa según la Letra A) del Anexo al Real Decreto 1667/1991, de 15 de noviembre.

¿Podría pensarse que cuando el art.15.2 DPAE incluye el adjetivo "fehaciente", está pensando en restringir el uso de la notificación electrónica a un servicio público de telecomunicación que desarrolle específicamente Correos y Telégrafos? Ese servicio existe en la actualidad, se denomina Servicio de Notificaciones Telemáticas Seguras y nos hemos referido a él un poco más arriba, pero no se había creado aún cuando se dictó el DPAE en 2003. Por tanto, creo que no es ese el sentido de la disposición autonómica, que en tal caso habría sido más explícita. Entiendo, por el contrario, que el Decreto andaluz simplemente persigue declarar que no basta cualquier mecanismo de constancia, como un simple acuse de recibo generado por el programa de mensajería electrónica del receptor sin valores añadidos, siendo exigibles, por el contrario, técnicas más robustas de acreditación y seguridad, y en concreto, de la firma digital reconocida del receptor.

Podemos concluir, por tanto, que el uso de la firma electrónica reconocida por parte del receptor del mensaje que impone el art.12.3 DPAE, produce la constancia fehaciente del acceso al contenido de la notificación que exige el art.15.2 DPAE, de tal manera que ambos preceptos se encuentran armónicamente relacionados. En punto a conciliarlos con el Derecho estatal común en el marco de las particularidades organizativas del procedimiento que corresponde disponer a las Comunidades Autónomas, como nos proponíamos hacer al inicio de este apartado, podemos salvar el texto invocando la ha-

\footnotetext{
${ }^{37}$ La Disposición Transitoria Novena LGTe 1998 atribuyó igualmente a Correos y Telégrafos el monopolio de prestación de estos servicios: "1. La entidad pública empresarial Correos y Telégrafos continuará prestando directamente los servicios de télex, telegráficos y otros de características similares, a los que alude el artículo 40.2.a) de esta Ley, ajustándose, en su caso, a lo que prevea el Real Decreto al que se refiere el apartado 3 de dicho artículo. Con tal objeto o con cualquier otro vinculado a sus fines propios, la referida entidad pública empresarial podrá participar mayoritariamente en sociedades, previa autorización, a propuesta de su Consejo de Administración, del Ministro de Fomento". Un análisis pormenorizado de esta norma en DE LA SERN BILBAO, M.N.: "Comentario a la Disposición Transitoria Novena", en Comentarios a la Ley General de Telecomunicaciones, op.cit., págs.824 y sigs.
} 
bilitación expresa que el art.59.3 LRJAP establece para que reglamentariamente se determinen por cada Administración pública los requisitos de la dirección electrónica del ciudadano: si bien este engarce resulta forzado y peregrino, suscitando alguna duda de legalidad (no parece que la exigencia de la firma electrónica reconocida pueda concebirse estrictamente como una característica técnica de la dirección electrónica, pues supone realmente un servicio añadido de telecomunicación), dos argumentos refuerzan esta interpretación: el primero, la precipitación con que se aprobó la modificación del art.59.3 LRJAP, dando lugar a graves imprecisiones -según ya hemos tenido ocasión de señalar anteriormente-, y exigiendo una interpretación coherente con el resto del ordenamiento jurídico como la que acabamos de ofrecer; y el segundo, que la Administración del Estado ha entendido la habilitación normativa en análogo sentido que la Junta de Andalucía, imponiendo exactamente el mismo requisito en las normas que desarrollan reglamentariamente el art.59.3 LRJAP -el Real Decreto 209/2003, de 21 de febrero, y la Orden PRE/1551/2003, de 10 de junio, citados-, y aunque la paridad normativa no puede interpretarse como requisito de validez (podrían ser ilegales tanto el Derecho estatal como el autonómico) no puede ignorarse su valor como elemento interpretativo del ordenamiento jurídico.

Ahora bien, como prudentemente advierte VALERO, este orden de cosas dejaría en manos del interesado el momento en que se perfecciona la notificación, de tal manera que le bastaría con no consultar el contenido de los mensajes para evitar que se produzca la notificación, por lo que resulta preciso definir una "regla supletoria temporal cuya aplicación venga determinada por circunstancias objetivas al margen de la actitud del interesado" 38 . Conviene tratar este problema separadamente, junto a otras cuestiones con las que guarda estrecha conexión.

d) Incidencias en la notificación por correo electrónico: rechazo tácito, supresión del segundo intento e imposibilidad de acceso al contenido.

El art.59.3 LRJAP, y el art.15.2 DPAE, pretenden resolver, en primer lugar, la eventualidad de que el ciudadano, que dispone ya de la notificación entregada en su buzón electrónico, no llegue a acceder al contenido del mensaje. Estos preceptos disponen que el rechazo -tácito- de la notificación electrónica se produce cuando el mensaje se encuentra disponible por espacio de

${ }^{38}$ Cfr. V ALERO TORRIJOS, J.: El régimen..., op.cit., pág.148. Por otra parte, a juicio del autor, esta misma necesidad determina que la notificación deba entenderse practicada cuando el interesado acceda a su buzón electrónico, y no cuando se descargue el mensaje a un equipo terminal. 
diez días en el buzón del destinatario sin que éste acceda a su contenido, lo que constituye una destacable especialidad de este medio de notificación, que excepciona el protocolo aplicable al resto de medios admitidos por la Ley. El cambio entraña una tergiversación de los hechos, operada de iure, pues no es lo mismo un rechazo (término que presupone la actitud deliberada de no ser notificado), que una simple omisión de acceso (que puede ser involuntaria y deberse a un mero descuido); por consiguiente, habría sido preferible que en este caso la Ley afirmara sencillamente que la notificación se entendería practicada a todos los efectos ${ }^{39}$, produciéndose una notificación tácita mejor que un rechazo tácito de la notificación.

Debe notarse, por otra parte, que el Derecho propio de Andalucía no exige la constancia "fehaciente" de la permanencia del mensaje en el servidor, a diferencia de lo que sucede con la constancia del acceso: basta, en este caso, con la mera constancia (no fehaciente) de la disponibilidad del mensaje. El problema reside, no obstante, en probar la entrega del mensaje en el buzón del destinatario, cuando el servidor en que se hospeda no radique en la esfera directiva de la Junta de Andalucía: ¿cómo puede tener constancia la Administración autonómica de que el mensaje ha sido efectivamente depositado en el buzón de un destinatario, cuando el servicio de mensajería electrónica se lo preste al ciudadano una empresa privada? La pregunta no tiene fácil respuesta, o mejor dicho, no la tiene en absoluto, salvo que reconozcamos que el ciudadano no es libre de designar cualquier dirección electrónica a efectos de notificaciones administrativas, sino tan sólo aquéllas que se sitúen bajo la órbita de la Junta de Andalucía o bien las que se hospeden en servidores de empresas que hayan suscrito con la Administración autónoma acuerdos específicos que contemplen este extremo ${ }^{40}$.

En otro orden de consideraciones, los preceptos en examen suprimen el segundo intento de notificación, que de acuerdo con las reglas generales debería tener lugar en el espacio de tres días y a distinta hora. Esta particulari-

\footnotetext{
${ }^{39}$ Esta crítica es compartida por BAUZÁ MARTORELL, F.J.: Procedimiento..., op.cit., rcágs.190 y sigs.; y V ALERO TORRIJOS, J.: El régimen..., op.cit., pág.153.

${ }^{40}$ En la Administración del Estado la cuestión se ha solventado mediante el desarrollo reglamentario, señalando los requisitos y obligaciones que asumen los prestadores del servicio de "dirección electrónica única" al ciudadano, entre los que se incluyen una serie de deberes de tipo documental que obligan al prestatario a remitir a la Administración certificaciones electrónicas que todas las incidencias que rodean a la notificación; vid la Orden PRE/155112003, de 10 junio, citada, y GAMERO CASADO, E.: Notificaciones telemáticas, op.cit., págs.210 y sigs.
} 
dad de la notificación por correo electrónico no deja de tener su lógica: el segundo intento encuentra su razón de ser en los medios de notificación de carácter inmediato, que no permiten el depósito del mensaje en algún lugar de donde el destinatario o su representante puedan retirarlo con mayor disponibilidad horaria dejando constancia del hecho ${ }^{41}$.

En relación con el plazo de permanencia de la notificación en el buzón del destinatario, se plantea VALERO la hipótesis de que la Administración pretenda retirarla una vez vencido dicho plazo perentorio arguyendo razones técnicas, como por ejemplo la limitación del espacio disponible; en su opinión, que suscribo plenamente, el mensaje debería permanecer en el servidor un período prudencial, toda vez que la falta de consulta puede deberse a un mero descuido del usuario y no a su intención deliberada, por lo que sugiere la permanencia del mensaje en tanto se encuentren abiertos los plazos de recurso contra el acto notificado ${ }^{42}$.

Por otra parte, y esta vez en garantía de los derechos de defensa del interesado, se permite a éste aportar prueba de la "imposibilidad técnica o material del acceso", afirmación que suscita dos consideraciones. Por una parte, la necesidad de acotar el alcance de la imposibilidad, que debe ser exclusivamente la que resulte imputable al proveedor del servicio de mensajería electrónica, y nunca a otro tipo de causas (enfermedad del destinatario, avería de su equipo terminal, o cualquier otra) que permitan al destinatario condicionar por sí mismo la validez de la notificación con gran facilidad: siendo re-

\footnotetext{
${ }^{41}$ Ahora bien, debo manifestar mi oposición respecto al agravio comparativo que ello representa sobre el destinatario cuando elige el correo electrónico como medio de notificación. Así, en el régimen jurídico de la notificación postal, el ciudadano dispone de dos intentos sucesivos de notificación, ambos con depósito de aviso en su casillero domiciliario y pase a lista del envío por espacio de un mes en el caso de no encontrarse presente en el domicilio; cuando después de todo esto no se logra el objetivo, se procede a la publicación sustitutiva del acto, y no a proseguir los trámites del procedimiento por entenderse tácitamente rechazada la notificación. Por el contrario, en la notificación por correo electrónico, basta con que se encuentre disponible en el buzón del destinatario durante diez días para que se entienda rechazada tácitamente, en lugar de procederse a su publicación sustitutiva. En principio, la opción seguida por el art.59.3 LRJAP me parece perfectamente admisible; pero lo que no puedo compartir es la asimetría de criterio entre ambos medios de notificación, tanto más, cuanto que el postal viene derivado de una norma meramente reglamentaria -el Real Decreto 1829/1999, de 3 de diciembre, por el que se aprueba el Reglamento por el que se regula la prestación de los servicios postales - que lleva a cabo una interpretación de la Ley ciertamente favorable para los interesados. Sería coherente solventar este orden de cosas unificando el criterio en una futura reforma legislativa.
}

42 Vid. V ALERO TORRIJOS, J.: El régimen..., op.cit., págs. 134 y sigs. 
quisito sine qua non para el empleo de este medio de notificación el previo consentimiento del destinatario, parece justo que recaiga sobre él toda incidencia relativa a su esfera personal y no al mal funcionamiento del servidor, porque de otro modo la eficacia del acto queda excesivamente condicionada por avatares que no le son imputables a la Administración en modo alguno ${ }^{43}$. Entiendo, por tanto, que la expresión "imposibilidad técnica o material' no comprende toda situación en que haya sido materialmente imposible el acceso al buzón, sino que se contrae a las circunstancias en las que el acceso no ha podido tener lugar por razones materiales, esto es, imputables a circunstancias estrictamente objetivas y específicamente relacionadas con el servidor de correo electrónico o con el prestador de servicios de certificación que interviene en el proceso de notificación.

Por otra parte, el precepto no establece las consecuencias que derivarían de esta comprobación, de modo que no sabemos lo que debe ocurrir cuando se demuestre la imposibilidad técnica o material del acceso: está claro que no puede entenderse el supuesto como rechazo de la notificación, pero no se determina si la Administración deberá proceder a un segundo intento por el mismo medio o por otro diferente, o bien puede interpretarse esta incidencia como una notificación infructuosa y procederse a la notificación sustitutiva mediante edictos y publicación en el diario oficial que corresponda en aplicación del art.59.5 LRJAP. En el caso de que se opte por repetir el intento de notificación, queda también sin respuesta legal el modo de efectuar el cómputo del plazo de depósito, pues la Ley no define si se reanudará el plazo en el punto en que se interrumpió la disponibilidad del mensaje -culminando lo que res-

\footnotetext{
${ }^{43}$ Por el contrario, para V ALERO TORRIJOS, J.: El régimen..., op.cit., págs.155 y sigs., cuando la causa que impide al acceso se sitúa en el ámbito del destinatario sería preciso distinguir entre impedimentos objetivos y subjetivos. A juicio del autor, los primeros, relativos a circunstancias técnicas, no podrían bloquear la eficacia del acto cuando resulten imputables a un tercero (por ejemplo, fallos en el servidor que impiden acceder al buzón); y por el contrario, sí podrían determinar el carácter infructuoso de la notificación (sin conducir a su rechazo tácito) cuando la imposibilidad en el acceso viniera referida a los medios que permanecen bajo el control del interesado y éste hubiera demostrado la diligencia debida podría considerarse la existencia de una justificación suficiente. y en cuanto a las circunstancias subjetivas, esto es, atinente s a circunstancias personales del destinatario, opina el autor que podría considerarse la existencia de una justificación suficiente cuando la entidad del problema sea tal que, aún empleando toda la diligencia debida, no pudiera conectarse a su dirección electrónica para recibir la notificación.

En mi opinión, esta construcción es excesivamente voluntarista y no casa bien con la práctica seguida en el resto de medios de notificación. Por ejemplo, en el caso de las notificaciones postales, de ser infructuoso el segundo intento se procede sin mayor escrúpulo a la publicación sustitutiva del acto, siendo indiferente que la ausencia del domicilio viniera motivada por el disfrute de vacaciones o por un ingreso hospitalario.
} 
te hasta el total de diez días-, o bien se concederá de nuevo el plazo íntegro - diez días completos- a efectos de cómputo de un eventual rechazo tácito posterior. Por añadidura, cuando la Administración no reciba acuse de recibo de la notificación en el plazo de diez días, podrá desconocer si ello se debe a la desidia del destinatario (que simplemente no descargó su correo), o a la existencia de problemas en el servidor, por lo que no sabrá a ciencia cierta si debe entender presuntamente rechazada la notificación o no ${ }^{44}$. En mi opinión, debido a todo lo anterior, lo prudente será que cuando el destinatario no recoja su mensaje la Administración proceda siempre a la publicación sustitutoria mediante edictos y en el diario oficial que corresponda, asegurándose así en todo caso la eficacia de la resolución.

En cualquier forma, y esto es importante notarlo, creo que conforme al art.58.4 LRJAP, con la puesta a disposición del mensaje en el buzón del destinatario se debe entender satisfecho el requisito del intento de notificación en plazo a efectos de impedir la producción de un acto presunto estimatorio, cuando fuera el caso ${ }^{45}$. Esto concuerda con la doctrina contenida en la STS de $17 / 11 / 03$, rec.128/2002, en cuya virtud, para entender concluso un procedimiento administrativo dentro del correspondiente plazo máximo, basta con realizar un intento documentado de notificación por cualquier medio legalmente admisible según los términos del art.59 LRJAP, aunque finalmente dicho intento se revele infructuoso ${ }^{46}$.

\footnotetext{
${ }^{44}$ No obstante, en el concreto caso de la Administración del Estado, la Orden PRE/1551/03, de 10 de junio, citada, impone al prestador del servicio de dirección electrónica única que certifique puntualmente cualquier fallo técnico que haya impedido el acceso al servidor, lo que elimina este problema. Distinto puede ser el régimen instaurado por otras Administraciones públicas en virtud de su capacidad reglamentaria en la materia.

${ }^{45}$ Es también la opinión de V ALERO TORRIJOS, 1.: El régimen..., op.cit., pág.154.

${ }^{46}$ La doctrina legal fijada por la Sentencia, que se dicta en resolución de un recurso de casación en interés de Ley, es la siguiente: "'Que el inciso intento de notificación debidamente acreditado que emplea el artículo 58.4 de la Ley 30/1992, de 26 de noviembre, de Régimen Jurídico de las Administraciones públicas y del Procedimiento Administrativo Común, se refiere al intento de notificación personal por cualquier procedimiento que cumpla con las exigencias legales contempladas en el artículo 59.1 de la Ley 30/1992, pero que resulte infructuoso por cualquier circunstancia y que quede debidamente acreditado. De esta manera, bastará para entender concluso un procedimiento administrativo dentro del plazo máximo que la ley le asigne, en aplicación del referido artículo 58.4 de la Ley 30/1992, el intento de notificación por cualquier medio legalmente admisible según los términos del artículo 59 de la Ley 30/1992, y que se practique con todas las garantías legales aunque resulte frustrado finalmente, y siempre que quede debida constancia del mismo en el expediente.
} 


\section{4.- Notific@: el Sistema de Notificaciones Telemáticas de la Junta de Andalucía.}

a) Descripción general.

En abril de 2005 la Junta de Andalucía ha puesto en marcha el servicio Notific@ - o Sistema de Notificaciones Telemáticas- integrado en el conjunto de acciones que comprende el programa Administración electrónica, adscrito a la competencia de la Dirección General de la Administración Electrónica y Calidad de los Servicios, dependiente de la Secretaría General de Administración Pública de la Consejería de Justicia y Administración Pública. El sistema cuenta con una sección específica en el portal institucional-divulgativo de la Junta de Andalucía, siendo accesible en la URL http://www.andaluciajunta.es/notificaciones. Esta es su página principal:

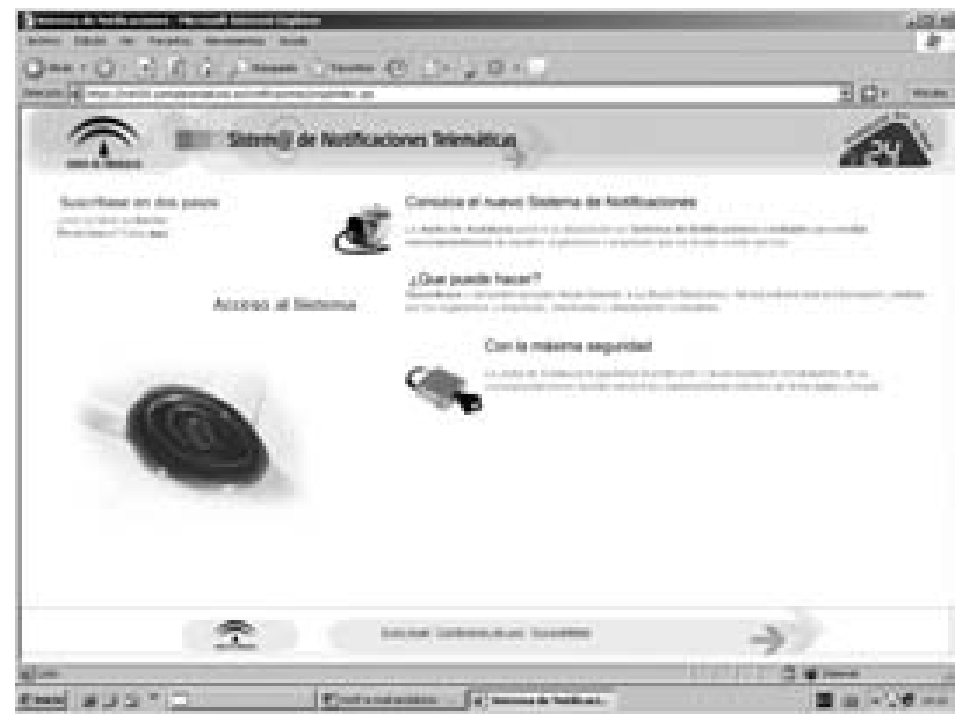

En relación con la práctica de la notificación por medio de correo certificado con acuse de recibo, el intento de notificación queda culminado, a los efectos del artículo 58.4 de la Ley 30/1992, en el momento en que la Administración reciba la devolución del envío, por no haberse logrado practicar la notificación, siempre que quede constancia de ello en el expediente”. 
Este sistema de notificaciones cuenta con el magnífico apoyo de un portal de carácter técnico, que expone los elementos esenciales de la Administración electrónica de la Junta de Andalucía, y que resulta accesible en http://ws024.juntadeandalucia.es

El propio portal describe los rasgos generales de este sistema de notificaciones en los siguientes términos (en cursiva, que son nuestras, sus elementos más significativos):

"El Servicio de Notificaciones Telemáticas Seguras de la Junta de Andalucía es el sistema que utiliza la Junta de Andalucía para realizar el envío y seguimiento de notificaciones telemáticas fehacientes, con generación de evidencias comprobables de la entrega por el emisor y la recepción por el destinatario. Este servicio está previsto en el Decreto $183 / 2003$, de 24 de junio, por el que se regula la información y atención al Ciudadano y la tramitación de los procedimientos administrativos por medios electrónicos (Internet) y es conforme al Real Decreto 209/2003 de 21 de febrero por el que se regulan los registros y las notificaciones telemáticas, así como la utilización de medios telemáticos para la sustitución de la aportación de certificados por los ciudadanos y será proporcionado por la Junta de Andalucía de acuerdo con la legislación aplicable o cualquier otra norma que venga a modificar, ampliar o derogar aquélla.

- Constituye un nuevo instrumento de comunicación ciudadano-Administración

- Se requiere el consentimiento expreso del interesado.

- Solo para los procedimientos expresamente señalados por el interesado.

- La acreditación de fechas y horas de recepción del aviso de notificación y el acceso del interesado al contenido se realiza mediante sellado de tiempo con el Notario Electrónico de la Junta de Andalucía.

La Junta de Andalucía asegura de conformidad con la legislación aplicable la disponibilidad del servicio 7 días a la semana 24 horas al día. Para el acceso a este servicio el usuario deberá suscribirse. La suscripción posibilita al ciudadano o empresa el acceso a las notificaciones procedentes de los diferentes Órganos y Organismos y emitidas telemáticamente, cuyo destinatario sea el propio usuario. La suscripción al servicio solamente obliga a la Junta de Andalucía respecto del alta en el servicio, el acceso al Buzón Electrónico, la garantía de la correcta distribución de notificaciones a los usuarios y la baja del servicio de acuerdo con lo establecido en la legislación vigente. Por el hecho de mantener las notificaciones accesibles para el interesado, la Junta de Andalucía no se responsabiliza del contenido de las notificaciones, de los efectos jurídicos de las mismas ni de asegurar los efectos jurídicos que derivan de cada notificación.

(...)

Una vez puestas a disposición del usuario las notificaciones en su buzón electrónico personal, éste podrá:

- Leer el contenido de las notificaciones, generándose un acuse de recibo firmado y fechado electrónicamente que se remitirá al emisor de la notificación. 
- Rechazar una notificación antes de abrirla. El rechazo genera un acuse firmado y fechado y un procedimiento de seguimiento y gestión de rechazados, estipulados en la normativa vigente o en los procedimientos de la Administración emisora.

- Visualizar la lista de notificaciones de cada carpeta y de su estado: recibidos, leídos, rechazados y caducados.

- Consultar los acuses de recibo, de lectura y de rechazo, firmados y fechados asociados a cada notificación.

- Clasificar las notificaciones que aparecen en su vista personalizada del buzón de notificaciones. Para facilitar la organización de las notificaciones y documentos según sus preferencias el usuario podrá crear subcarpetas.

- Borrar de su vista personalizada del buzón una notificación o documento ya leído o rechazado.

- Obtener una copia impresa del mensaje que está viendo en su pantalla a través de su navegador, así como del fichero adjunto, en el caso de que lo hubiera.

Para asegurar el fechado de la recepción, envío, acceso a notificaciones, se realiza la sincronización de la fecha y la hora con el Real Instituto y Observatorio de la Armada.

Por consiguiente, el servicio Notific@, que es de carácter gratuito, supone la implantación de un sistema de notificaciones telemáticas respetuoso con las exigencias normativas que regulan la materia en el Derecho estatal básico y en las disposiciones autonómicas de desarrollo. No trae causa de una Orden específica de la Consejería de Justicia y Administración Pública, sino que disfruta directamente de la habilitación que concede el art.18 DPAE, en cuya virtud las aplicaciones, programas, medios y soportes instaurados en ejecución del Decreto serán aprobados y homologados por la Consejería de Justicia y Administración Pública de la Junta de Andalucía, sin necesidad de mayores concreciones normativas. Su homólogo, el Servicio de Notificaciones Telemáticas Seguras (SNTS) de la Administración del Estado, por el contrario, se ha beneficiado de un excelente soporte reglamentario específico, constituido por la Orden PRE/1551/2003, de 10 de junio, por la que se desarrolla la Disposición Adicional Primera del RDRNT: una disposición de excelente factura cuya emulación hubiera sido deseable, como veremos más tarde.

El servicio Notific@ colma todas las garantías jurídicas y todos los requisitos técnicos dispuestos por las normas de aplicación, previamente estudiados en los epígrafes anteriores. Su operativa es tremendamente simple, en especial para quienes dispongan previamente de un certificado digital. Veamos cómo tiene lugar. 
b) Altas y bajas en el sistema y en los concretos procedimientos en que opere.

Desde la página principal de Notific@ (http://www.andaluciajunta.es/notificaciones), una vez se pincha en la opción "darse de alta en el sistema", se ejecuta una aplicación específica que pide al usuario su identificación mediante el certificado digital reconocido que emite la FNMT (si no se dispone de él, habrá que obtenerlo antes de continuar). Cuando se acepta firmar digitalmente el intercambio aparece un formulario que le solicita sus datos personales: nombre y apellidos, dirección, teléfonos, dirección electrónica convencional, etc. En el caso de que pinche sobre la pestaña "Aceptar y firmar", el sistema ofrece un nuevo cuadro de diálogo en el que el usuario debe suscribir una declaración de conocimiento y comprensión del formulario que acaba de rellenar. Caso de que acepte nuevamente esta petición, se le aparece otro cuadro de diálogo más en el que se le solicita autorización para la ejecución on line de un programa de software que resulta preciso para proseguir el proceso. Dicha aplicación informática presenta al usuario los certificados digitales disponibles en su equipo para que firme el formulario de alta con uno de ellos. Cuando se acepta firmar digitalmente aparece el aviso: "Formulario firmado válidamente"; después de aceptar también este mensaje, aparece el aviso: "Alta realizada correctamente, a continuación se accederá al sistema", y hay que aceptar de nuevo. Al hacerlo, se accede propiamente al servicio de notificaciones telemáticas por primera vez, siendo requerido el usuario a que se identifique mediante su certificado digital. La generación del buzón electrónico por parte del sistema es velocísima, y en apenas unos minutos el usuario dispone ya de acceso al servicio. En conexiones sucesivas, para disfrutar propiamente del servicio bastará con pinchar en el enlace "Acceso al sistema" desde la página principal, tras de lo cual el usuario se identifica mediante firma digital. En ambos casos aparece esta pantalla: 


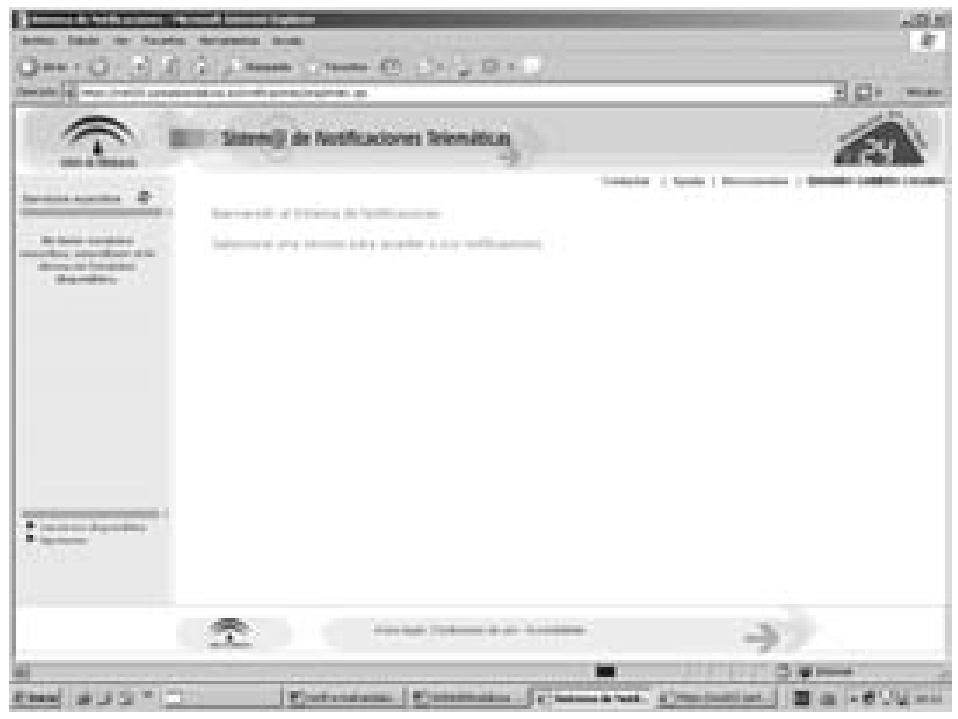

A continuación hay que suscribirse a las categorías concretas de procedimientos administrativos en los que deseamos recibir notificaciones telemáticas, pinchando el enlace del lado inferior izquierdo, titulado "Servicios disponibles". Al hacerlo, aparece el menú de Consejerías que tienen activados procedimientos en los que cabe realizar notificaciones telemáticas, y los concretos procedimientos en que opera el servicio.

Cada vez que se opta por suscribirse a las notificaciones telemáticas en un determinado procedimiento el sistema abre una pantalla en la que obliga al usuario a aceptar nuevamente las condiciones del servicio: 


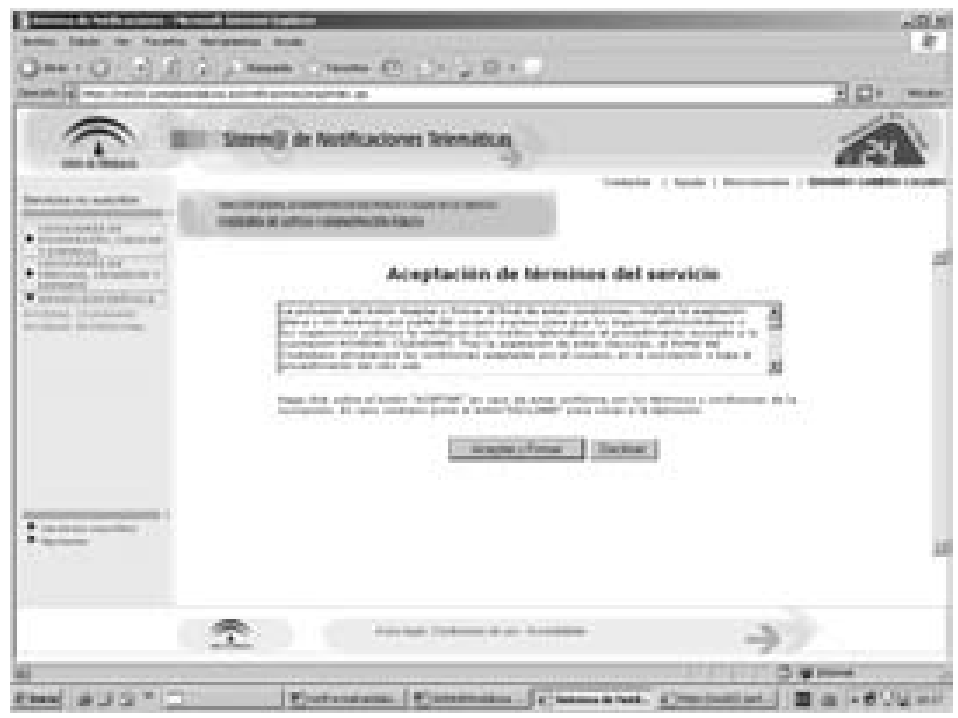

Una vez que se acepta, todavía aparece otro aviso más que dice: "Declaro que entiendo el contenido del formulario que me dispongo a enviar", hay que aceptar, y después firmar de nuevo digitalmente. Y después aparece el aviso "Formulario firmado correctamente", que hay que aceptar; y todavía después otro aviso que dice "Suscripción al servicio realizada correctamente" y también hay que aceptar. Al poco tiempo de cursar cada alta en un concreto procedimiento, el usuario recibe una notificación en su correo electrónico convencional (cuya dirección incluyó en el formulario de inscripción al darse de alta inicialmente en el sistema) en la que se le da la bienvenida en el servicio y se le ofrece el enlace al portal de Notific@.

Las altas en los diferentes procedimientos se gestionan por el usuario una a una. Para proceder a la baja en alguno de los procedimientos en cuestión hay que seguir un camino parecido al descrito, pero activando la opción de baja en cada procedimiento a que se encontrara previamente suscrito.

c) Gestión de las notificaciones.

El alta en Notific@ conlleva la creación de un buzón electrónico en el que se depositan las notificaciones administrativas dirigidas al suscriptor del servicio. El ciudadano no dispone de un nombre con que referirse a su cuenta de correo electrónico, esto es, lo que coloquialmente conocemos como dirección 
de correo electrónico: una serie de códigos alfanuméricos, el signo @ -arroba- y otra serie de códigos alfanuméricos vinculados por lo general a un nombre de dominio. De tal manera que el usuario de Notific@ no puede utilizar esta dirección electrónica para efectos distintos de las notificaciones administrativas, toda vez que no puede facilitar a terceros la ubicación de su cuenta de correo. Esto entraña que el sistema no entre en competencia con los servidores convencionales de mensajería electrónica, y también un ahorro de recursos, pues de este modo los buzones pueden tener una capacidad más reducida. No obstante, supone una importante restricción para los usuarios, que no pueden configurar sus programas de correo electrónico para descargarse automáticamente el contenido de esta cuenta específica con ocasión de su conexión a su proveedor habitual de servicios de Internet. La restricción comporta, igualmente, una expectativa de menor periodicidad en el acceso al buzón por parte del ciudadano, toda vez que se ve obligado a realizar ex profeso la operación a través de navegadores de Internet contactando nuevamente con el portal del sistema.

Este rasgo podría representar un gran demérito y un escollo indudable a la generalización de Notific@: difícilmente se arriesgará un ciudadano a ser notificado por un mecanismo que le exige consultar periódicamente un determinado portal de Internet, pues temerá olvidarse de hacerlo, y ya sabemos que la disposición del mensaje durante diez días en el buzón del destinatario equivale al rechazo de la notificación y permite a la Administración continuar el procedimiento sin más trámite. Pero esta minusvalía se resuelve del siguiente modo: cuando el usuario recibe una notificación telemática en Notific@, el servidor le envía un mensaje a la dirección electrónica convencional, esto es, la que el ciudadano facilitó con ocasión de su alta en el sistema, que previsiblemente será la que utilice de continuo y consulte con frecuencia, sin temor a que transcurra el plazo de depósito que habilita a proseguir el procedimiento sin haber consultado ese buzón usual de correo electrónico. El mensaje enviado a su dirección de correo convencional le advierte de la recepción de una notificación en Notific@, comunicándole que puede acceder a la misma a través del portal de Internet, haciendo constar el enlace directamente inscrito en el propio mensaje electrónico. Este protocolo de actuación permite conciliar la celeridad de la comunicación con la seguridad de la notificación. El sistema contempla la incorporación de un servicio de alerta semejante al descrito por medio de mensajes SMS enviados a un terminal de telefonía móvil, lo que puede ser aún más útil, pero también entraña algún riesgo dada su escasa fiabilidad.

Para acceder al portal de Notific@ a fin de gestionar el correo es preciso pinchar en la opción "Acceso al sistema”. Al hacerlo, el servidor pide en línea 
el certificado digital, y al confirmarlo se accede directamente al buzón del correo. El servicio funciona en modo webmail, es decir, que no opera mediante un programa independiente de mensajería electrónica instalado en el equipo del receptor -salvedad hecha de ciertas utilidades de software-, sino que se activa mediante conexión al servidor institucional de la Junta de Andalucía a través del navegador de Internet, lo cual es propio de sistemas bunkerizados (dotados de una rigurosa política de protección y seguridad), pues eleva considerablemente el nivel de los filtros y cortafuegos que el servidor puede erigir en prevención de potenciales ataques. Esto limita correlativamente las opciones del usuario. Así, el servidor no permite (al menos, de momento) enviar o reenviar mensajes, por lo que no es posible descargarse la notificación en otra dirección, o grabarla en algún tipo de soporte electrónico a fin de operar con los archivos correspondientes, por ejemplo, para conservar una copia, para remitirlos por vía telemática -a un abogado o asesor, a la pareja-, o a cualquier otro fin. En cualquier caso, sí se conserva copia de la notificación en el sistema, pudiendo consultarse por el usuario cuantas veces lo precise.

La página del navegador ofrece el listado de mensajes (notificaciones) disponibles en el buzón. Cuando se pincha sobre una notificación que todavía no ha sido leída por el usuario se le pregunta si desea acceder a su contenido, lo que pretende permitir al ciudadano optar por el rechazo de la notificación en ejercicio de las diferentes posibilidades que le ofrece la Ley; se notará que elegir el rechazo supone dar por practicada la notificación de igual manera que si accediera a su contenido. Esta opción resulta ciertamente llamativa, pues no le encontramos acomodo en el apartado $3^{\circ}$ del art.59 LRJPAC, que, como sabemos, construye un régimen específico de notificación para la mensajería electrónica: debemos justificar su aparición acudiendo al apartado $3^{\circ}$ del mismo artículo. Y esto siembra la duda de determinar si la notificación por correo electrónico regulada por el art.59.3 LRJPAC puede llegar a servirse de ciertas reglas o preceptos relativos al resto de medios de notificación que se encuentran previstos para evitar que el acto notificado no alcance eficacia. Entiendo que, tratándose de una previsión restrictiva de derechos, debería encontrarse expresamente prevista por el apartado $3^{\circ}$ para resultar aplicable a las notificaciones electrónicas, sin que sea posible realizar una interpretación extensiva del apartado $4^{\circ}$ del art.59.

Cuando el usuario opta por leer el mensaje, automáticamente se genera un acuse de recibo con garantía de no repudio, que queda registrado electrónicamente en el sistema, y al que el ciudadano puede acceder posteriormente a efecto de recordar en qué fecha accedió al contenido de la notificación, momento en el que como es sabido adquiere eficacia el acto administrativo notificado. 
La herramienta empleada por el sistema para transmitir al usuario la notificación es el envío de un fichero adjunto al mensaje de correo electrónico en el que se le da traslado del contenido íntegro del acto a notificar, firma incluida. El sistema permite imprimir ese documento para que el receptor disponga de una copia en papel del acto notificado. Normalmente este fichero adjunto se construye en formato pdf: el empleo de un fichero Acrobat permite firmar digitalmente el documento y que el receptor compruebe la autenticidad de dicha firma, así como detectar las modificaciones o manipulaciones de que sea objeto posteriormente el documento, lo cual lo erigen en el soporte ideal de este tipo de transacciones.

El servidor facilita una serie de utilidades, como la gestión de carpetas (creación, modificación, supresión), el borrado definitivo de mensajes, su copiado a carpetas específicas, etc. En el futuro, además, se activará una función de alerta de recibo de notificaciones a través de SMS, esto es, de mensajería electrónica en terminales de telefonía móvil. Por lo demás, y como es lógico, el sistema reúne todos los requisitos de seguridad, normalización técnica y conservación exigidos por la normativa vigente.

\section{d) Recapitulación crítica.}

El conjunto de operaciones que comprende una notificación telemática segura puede resumirse mediante el siguiente gráfico ${ }^{47}$, donde el "Notario electrónico" es el prestador de servicios de certificación (un tercero de confianza acreditado para prestar servicios de certificación digital, o third trust party, quien garantiza la neutralidad de la fuente; en el caso de la Junta de Andalucía, esta plataforma es la constituida Ancert, la Agencia Notarial de Certificación), la "Entidad" es el órgano u organismo de la Junta de Andalucía que pretende enviar la notificación, y el "Usuario", el ciudadano suscrito a Notific@.

47 Obtenido de la presentación de Notific@, preparada por Luis NA V ARRO y Antonio SERRANO, accesible en http://ws024.iuntadeandalucia.es (portal técnico de soporte a la Administración Electrónica de la Junta de Andalucía). 


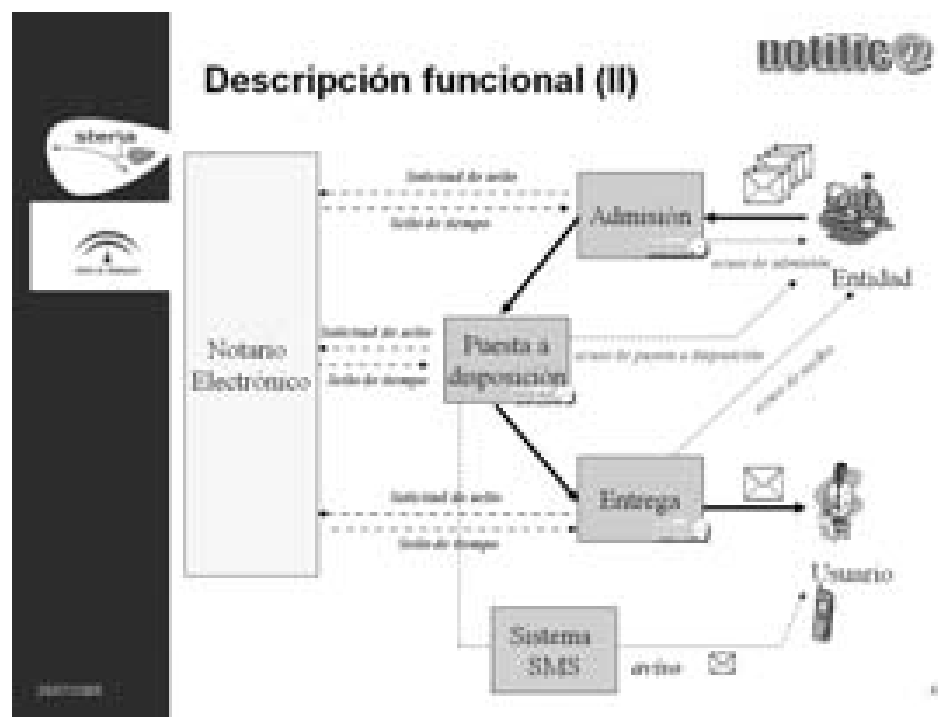

El Sistema de Notificaciones Telemáticas Notific@ es ciertamente impecable en su factura. Constituye una clara apuesta por consolidar las nuevas tecnologías de la información en la gestión administrativa ordinaria de la Junta de Andalucía, erigiéndose en una poderosa herramienta para el impulso del Gobierno electrónico. Se trata de una auténtica estafeta electrónica de la Junta de Andalucía, mediante la que proceder, con plenitud de garantías técnicas y jurídicas, a la notificación formal de actos administrativos.

Sin embargo, cabe preguntarse si verdaderamente era preciso desplegar estos impresionantes medios para alumbrar un sistema propio de notificación telemática en Andalucía, sobre todo cuando percibimos que su dinámica de funcionamiento es muy similar a la que se ha seguido por Correos y Telégrafos para implantar el SNTS ${ }^{48}$; sobre todo, cuando reparamos en que la Disposición Adicional 4aㅡ del Real Decreto 263/1996, de 16 de febrero, por el que se regula la utilización de técnicas electrónicas, informáticas y telemáticas por la Administración General del Estado (añadida por el Real De-

48 Sobre el particular, véase GAMERO CASADO, E.: Notificaciones telemáticas, op.cit., págs. 226 y sigs.; y el portal del SNTS, accesible en http://www.notificaciones.administracion.es 
creto 209/2003), contempla la firma de convenios de colaboración de la Administración del Estado con otras Administraciones públicas a fin de extender el SNTS a procedimientos tramitados por las mismas. Este dato, unido a la ubicación del servicio en una URL vinculada al portal general de las Administraciones públicas, evidencia que la íntima vocación del SNTS es la de erigirse en la dirección única a efectos de notificación de toda suerte de actos administrativos, con independencia de cuál sea la Administración notificante.

La Junta de Andalucía obró con gran sensatez, a mi juicio, cuando renunció a crear una forma digital propia para asumir la general que facilita la FNMT, en virtud de un convenio de colaboración que está prestando innegables servicios a los ciudadanos andaluces. Es muy escaso el número de procedimientos a los que los ciudadanos pueden suscribirse todavía para ser notificados telemáticamente. A ello se le suma que ese listado no se integra con el relativo a la Administración del Estado, sino que exige a los interesados darse de alta en dos servicios diferentes de notificación telemática. No es previsible que se muestren muy dispuestos a hacerlo, al menos en tanto que el número de procedimientos sea significativo, o que se trate de un ciudadano que, por su perfil profesional específico, tramite un gran número de procedimientos y se relacione frecuentemente con la Junta de Andalucía, a lo que se debe añadir que conozca suficientemente las nuevas tecnologías y que se muestre partidario de su empleo.

Sin embargo, la adhesión al sistema de notificaciones de Correos y Telégrafos planteaba grandes dificultades de orden técnico, que no resultaron posibles de salvar debido a la rigidez de dicho sistema. Por ejemplo, la Junta de Andalucía ha apostado decididamente por el uso de software libre (empleando el sistema operativo Linux), lo que resulta incompatible el empleo exclusivo de los navegadores que operan con el SNTS (Internet Explorer y Netscape). A esto se le añade que el sistema criptográfico elegido por el SNTS también es excluyente y propio de Microsoft. Todo ello supone, además, que en el caso de aceptarse este sistema de notificaciones la Junta de Andalucía habría de asumir grandes costes en concepto de licencia por utilización de estas aplicaciones; en cambio, el manejo del software libre le exime de estos gastos. Finalmente, el desarrollo del sistema Notific@, impulsado por la propia Dirección General de la Administración Electrónica a través de la empresa Steria, ha resultado más económico que la adhesión a un sistema de notificaciones previamente creado por la Administración del Estado. Algo funciona mal en las relaciones interadministrativas cuando se llega a estos extremos de incomprensión. 


\section{4.- NOTIFICACIONES ELECTRÓNICAS AUTONÓMICAS EN EN- TORNOS ESPECÍFICOS}

\section{1.- La mensajería electrónica en redes intranet y en relaciones de suje- ción especial.}

Una intranet es la red de telecomunicación informática que conecta internamente entre sí los equipos de una determinada organización, quedando la gestión y administración de la red bajo su propio control. Esta red intranet puede a su vez conectarse a otras redes para construir "telarañas": Internet, es, precisamente, una telaraña mundial (world wide web o w3) compuesta por una infinidad de conexiones entre redes informáticas intranets.

Existe una gran cantidad de redes intranet dependientes de las Administraciones públicas, por las que los mensajes electrónicos circulan de manera fiable y bajo la supervisión de un administrador del sistema dotado de la condición de funcionario público, quien puede certificar los intercambios electrónicos habidos en el dominio gracias a los mecanismos de traza con que se encuentran provistos los servidores de mensajería electrónica, que permiten incluso señalar desde qué localización IP se ha enviado y/o descargado un mensaje en un equipo terminal. El gráfico siguiente muestra la intranet administrativa de la Administración General del Estado, que interconecta todos sus órganos y organismos en un nodo central que registra todas las comunicaciones $^{49}$. Se observa, además, que esta red se conecta también, mediante un centro de acceso directo, con las redes intranet de las Comunidades Autónomas, Entidades Locales y Unión Europea, sin atravesar otros nodos intermedios, lo que permite mantener las comunicaciones en entornos situados bajo el control de las correspondientes Administraciones públicas y con el respeto de sus respectivas políticas de seguridad.

${ }^{49}$ La imagen se ha obtenido de AA.VV.: Criterios de seguridad..., op.cit., libro "Criterios de normalización”, pág.5. 


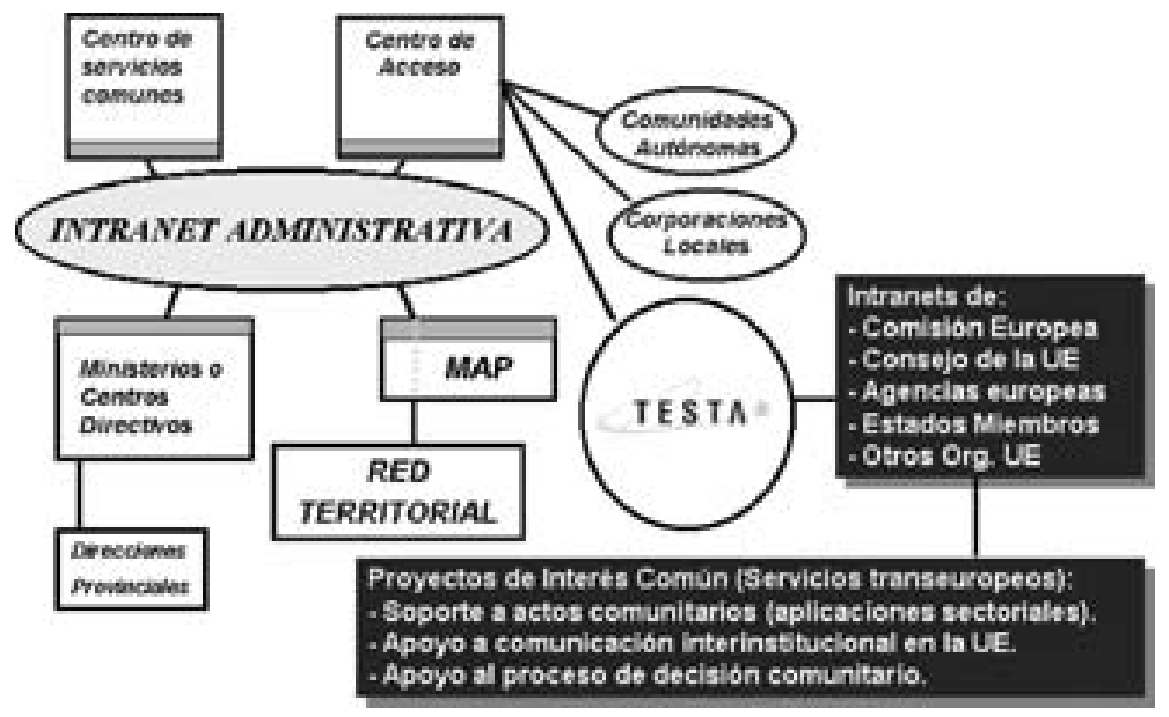

A estas garantías de seguridad se les asocia el poder de sujeción especial que la Administración ejerce sobre su personal ${ }^{50}$, que le permite implantar un sistema de mensajería electrónica para todo tipo de comunicaciones, facilitando a cada efectivo un buzón personal dotado de clave secreta de acceso y responsabilizándole de su custodia ${ }^{51}$, estableciendo expresamente mediante una norma reglamentaria (reglamento organizativo) el citado servicio de mensajería electrónica como medio de notificación interno.

A mi juicio, para garantizar la plena eficacia de una notificación por correo electrónico en una red intranet administrativa, llegando incluso a impo-

\footnotetext{
${ }^{50}$ En lo que se refiere al concepto de situación de sujeción especial, y su aplicación a la del personal de las Administraciones públicas, vid por todos LÓPEZ BENÍTEZ, M.: Naturaleza y presupuestos constitucionales de las relaciones especiales de sujeción, Universidad de Córdoba-Civitas, Madrid, 1994, págs.358 y sigs. y págs.383 y sigs.; GARCÍA MACHO, R.: Las relaciones de especial sujeción en la Constitución española, Tecnos, Madrid, 1992; y LASAGABASTER HERRARTE, 1.: Las relaciones de sujeción especial, IV AP-Civitas, Madrid, 1994, págs.233 y sigs.
}

${ }^{51}$ Como decíamos anteriormente, para BARRIUSO RUIZ, C.: La contratación electrónica, op.cit., pág.51, las claves personales garantizan la identidad en la operación telemática, de modo que su cesión por su titular a un tercero le hace personalmente responsable de las consecuencias que de ello pudieran derivarse, por negligencia en su custodia y secreto; el autor considera que la cesión de estas claves equivale a la cesión de la identidad, y que cuando no es posible garantizar su secreto el sistema no es válido. 
nerla preceptivamente en relaciones de sujeción especial (al personal de las Administraciones públicas) sería conveniente colmar las siguientes exigencias:

$\left.1^{\circ}\right)$ La dotación de direcciones electrónicas a todos los sujetos a que se aplique la medida, con asignación de clave personal y secreta de acceso, y del hardware y el software necesario para acceder al servidor;

$2^{\circ}$ ) La responsabilización a los usuarios del uso y custodia de su clave;

$3^{\text {o) }}$ La configuración automática de todos los envíos con acuse de recibo, archivando éste en el expediente (recordemos en este sentido que el propio expediente puede ser electrónico en su integridad, no siendo preciso su archivo en soporte papel); y

$4^{\text {a }}$ ) La designación de un administrador del sistema que pueda emitir un certificado de la circulación de documento por la red intranet, mediante las trazas del mensaje conservadas en el servidor.

A mi modo de ver, en estas circunstancias se cumplen todos los requisitos anteriormente apuntados para que el documento que certifica esas transacciones (ya sea electrónico, o posteriormente impreso en soporte papel) adquiera la condición de documento público administrativo, dando fe de que ese intercambio electrónico tuvo lugar, sin que sea necesario (aunque sí conveniente) la articulación de algún sistema de firma electrónica del documento, tanto más, cuanto que la firma no es requisito para el valor probatorio ni siquiera en los documentos en soporte papel ${ }^{52}$. Esta certificación puede completarse con el archivo en el expediente de la copia electrónica o impresa del mensaje enviado, y si el envío se configuró con aviso de recibo, también podrá incluirse éste. Todo ello concuerda, además, con el art.12.1 DPAE -cuyo texto íntegro transcribimos al inicio del $\S 3$ de este trabajo-, que constituye el marco normativo general de referencia sobre la transmisión y recepción de documentos electrónicos en el Derecho propio de Andalucía.

Cabe notar que en algunas Administraciones públicas se ha implantado con naturalidad el correo electrónico como medio de notificación. Por ejemplo, las convocatorias de los órganos administrativos colegiados de las universidades suelen realizarse por este medio, sin que se haya cuestionado su validez ${ }^{53}$.

52 Vid. GAETE GONZÁLEZ, E.A.: Instrumento..., op.cit., pág.95.

${ }^{53}$ Véase, por ejemplo, la STSJ Galicia de 28/11/01, rec.1702/1999, que se pronuncia sobre la validez de un reglamento aprobado por un Claustro Universitario convocado mediante correo electrónico; el medio de notificación por el que se efectuó la convocatoria no es ni tan siquiera objeto de discusión por el recurrente, que no lo alega como motivo de invalidez del acuerdo. 
A mi juicio, dándose todas estas circunstancias, nada impide conceder pleno valor a la notificación realizada mediante un sistema de mensajería electrónica ${ }^{54}$. Quizá convenga puntualizar que en el caso de acontecer alguna incidencia, el interesado siempre podrá ofrecer prueba a contrario de que no recibió el mensaje, destruyendo la presunción que beneficia a la Administración.

\section{2.- Notificaciones administrativas remitidas al "correo electrónico del ciudadano" facilitado por la propia Junta de Andalucía.}

La Junta de Andalucía ofrece un servicio gratuito de mensajería electrónica, denominado "correo electrónico del ciudadano" (CEC), que se encuentra regulado por la Orden de la Consejería de Presidencia de 7 de mayo de 2003 (BOJA no 87, de 9 de mayo), sobre correo electrónico del ciudadano. El servicio, que se facilita gratuitamente a todos los andaluces mayores de 14 años y a quienes se encuentren asociados a Comunidades Andaluzas asentadas fuera del territorio de la Comunidad Autónoma, consiste en un buzón alojado en el servidor institucional de la Junta de Andalucía, al que se asocia una dirección bajo el dominio "andaluciajunta.es", y dispone de prestaciones ciertamente avanzadas: $10 \mathrm{MB}$ de capacidad, acceso remoto mediante cualquier programa de correo electrónico, y acceso vía webmail mediante una aplicación informática que permite gran variedad de herramientas de gestión de archivos y carpetas.

El alta en el servicio es rapidísima, pues se gestiona on line a través del portal "Andalucía Junta", en el que dispone de una sección específica accesible directamente en la URL http://correo.andaluciajunta.es, aunque también puede llegarse hasta ella a través de la página principal http://www.andaluciajun$\underline{\text { ta.es }}$, pinchando en el enlace directo a "correo" que figura en la misma. La imagen de la página principal de este servicio es la siguiente:

${ }^{54}$ En la misma opinión parece situarse TORRES LÓPEZ, M.A.: "El documento.. .", op.cit., pág.258, quien entiende que el correo electrónico debe reputarse un medio válido de notificación en las relaciones ad intra de las Administraciones públicas. 


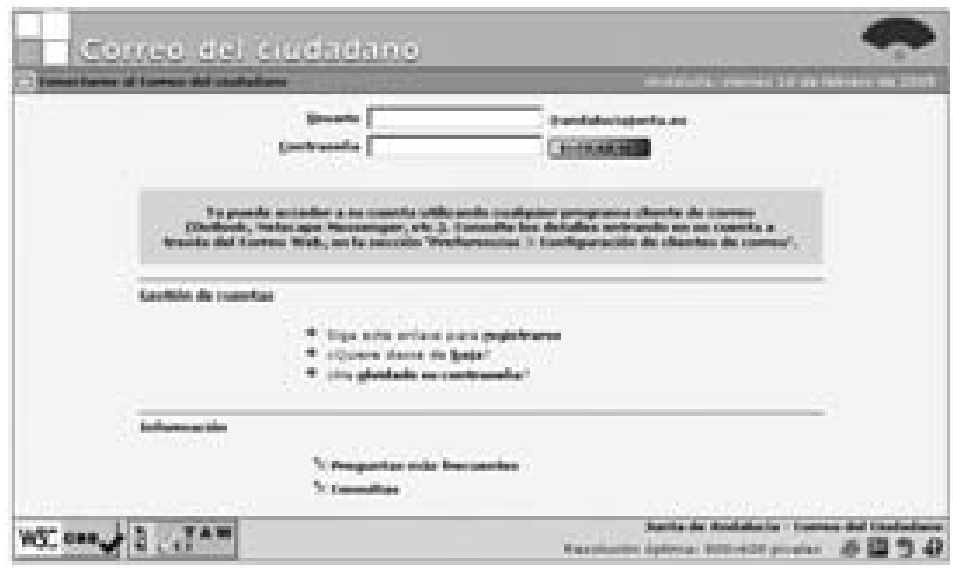

El servicio no tiene el objeto específico de soportar el envío de notificaciones administrativas, incardinándose entre las medidas de impulso de la sociedad del conocimiento en Andalucía que promueve el Decreto 72/2003, de 18 de marzo, que en su art.30 preveía expresamente su puesta en marcha. Pero indudablemente, puede ser el germen de un servicio propio de notificaciones administrativas por correo electrónico desarrollado por la propia Junta de Andalucía, en sentido análogo al Servicio de Notificaciones Telemáticas Seguras que actualmente presta el Ministerio de Administraciones Públicas a través de Correos y Telégrafos. En este sentido, la Comunidad Autónoma ya tiene suscrito con la FNMT el correspondiente convenio que permite obtener gratuitamente el certificado digital que facilita la FNMT, y que opera actualmente en las operaciones telemáticas entabladas entre los ciudadanos y la Administración de Andalucía.

\section{3.- La mensajería electrónica convencional como último y desesperado re- curso.}

Si la Administración autonómica no cuenta con ningún otro medio de notificación, y con su inactividad se arriesga a propiciar la generación de un acto presunto, puede al menos intentar la notificación por un servicio convencional de mensajería electrónica, lo que le permite disfrutar de una mínima constancia de la notificación, aunque se arriesgue después a que el juez, en ejercicio de la sana crítica, entienda que no puede probarse que la notificación tuvo lugar. Como ya hemos dicho, la notificación sería perfectamente 
válida (existe constancia de haberse practicado), pero su prueba goza de menos valor que la contenida en documentos públicos administrativos.

Aunque a efectos de valoración de la prueba la LECiv trate por igual a todos los documentos electrónicos e informáticos, puede señalarse una cierta gradación en la seguridad de los intercambios telemáticos, como ya sabemos; por consiguiente, el enjuiciamiento de acuerdo con la sana crítica debería reconocer mayor consistencia a los documentos electrónicos e informáticos en cuya generación se ha preservado un mayor grado de seguridad. Aunando esta circunstancia con el hecho de que el interesado ha podido indicar una dirección electrónica como destino de las notificaciones, lo que le hace responsable de su clave y en cierto sentido presume una aceptación por su parte de los riesgos que entraña el intercambio electrónico, podríamos identificar cuatro niveles de robustez en la prueba de recepción de un mensaje electrónico, que del más sólido al más débil serían los siguientes: 1) El ciudadano indica dirección electrónica y dispone de firma digital avanzada; 2) El ciudadano indica dirección electrónica y dispone de clave de acceso o PIN; 3) El ciudadano no indica dirección electrónica, dispone de firma digital avanzada y la Administración le notifica de oficio con acuse de recibo; 4) El ciudadano no indica dirección electrónica, sólo dispone de clave de acceso o PIN y la Administración le notifica de oficio con acuse de recibo. Todas estas alternativas serían válidas, a mi juicio, sin necesidad de que se satisfagan otros requisitos específicos del art.59.3 LRJAP, y sin que en este caso la Administración pueda beneficiarse del régimen que dicho precepto establece en relación con el rechazo de la notificación o la eventual omisión del segundo intento.

Existen algunas sentencias del orden contencioso-administrativo que ponderan el valor probatorio de los mensajes de correo electrónico cursados mediante servidores convencionales, sin garantías específicas de integridad, autenticidad, no repudio y sellado de fechas. Por ejemplo, la STSJ Asturias de 13/9/02, recs.2339/2001 y 2551/2001, anula una sanción administrativa impuesta por la Real Federación Colombófica Española en razón de la difusión mediante correo electrónico de una serie de afirmaciones que se entendieron contrarias al decoro deportivo; la Sala no concede valor probatorio alguno a los correos electrónicos en que se apoya la sanción, por entender que no se han practicado pruebas o comprobaciones para asegurar que el remitente era realmente el imputado, prueba que la Sala entiende imperativa debido a la posibilidad de remitir esos correos desde "distintos servidores" ${ }^{55}$. En términos

\footnotetext{
${ }^{55}$ El fundamento jurídico 50 de la Sentencia se expresa así: "Los argumentos que se contienen en el Fundamento anterior resultan sin embargo insuficientes para entender que no se ha vulne-
} 
análogos se expresa la SAN de 13/12/00, rec.320/1999, en la que se entiende que un escrito de recusación se presentó extemporáneamente al no existir constancia de la recepción de un correo electrónico enviado por el recusan$\mathrm{te}^{56}$. En ambos pronunciamientos se entrevé que, de haberse aportado pruebas de refuerzo, sí se habría concedido algún valor a los envíos por correo electrónico. En la misma línea, la STSJ Comunidad Valenciana de 13/11/00, rec.1155/2000 razona en sus fundamentos jurídicos acerca de la existencia en el expediente de un correo electrónico que se aporta como prueba documental, y efectivamente pondera y valora su contenido a efectos del fallo.

De otro lado, el art.29.3 de la Ley 17/2001, de 7 de diciembre, de Marcas, admite la posibilidad de que se practiquen notificaciones por correo electrónico cuando así lo solicite el interesado; dado que el precepto es anterior a la modificación del art.59 LRJAP introducida mediante la Ley 24/2001, solo cabe concluir que esta alusión es relativa a cualquier servicio de mensajería electrónica, sin especiales requisitos de seguridad, hipótesis que concuerda con la mención al fax que contiene el mismo precepto ${ }^{57}$, por tratarse de un medio que tampoco permite reunir pruebas fehacientes de la notificación. La elección de este medio de notificación por el interesado se encontraría entonces respaldada por el principio non venire contra actum proprium, que impediría al destinatario alegar la falta de constancia de la notificación como consecuencia del empleo de este medio.

Debe notarse, por otra parte, que el art.12 LSSI establece un deber de conservación de datos de transacciones electrónicas que recae sobre los pres-

rado el derecho a la presunción de inocencia que se recoge «in fine» del artículo 24.2 de la Constitución Española, pues si bien existe un inicio de prueba de cargo suficiente para determinar los hechos constitutivos de la infracción perseguida, derivada del contenido de los escritos publicados por internet a nombre del demandado con la dirección de su correo electrónico, resulta insuficiente para deducir que el autor material de dichos escritos lo fuera el demandado al omitirse toda prueba o comprobación para asegurar que la persona que aparece como remitente lo hubiera sido en la realidad ante la posibilidad de emitir «e-mail» con la dirección electrónica correspondiente a otra persona a través de distintos servidores".

${ }^{56}$ En el fundamento jurídico 70 se afirma: "ningún valor cabe dar a la remisión que la parte actora dice haber efectuado el 5 de enero de 1999 por correo electrónico y del que no hay constancia fehaciente, ni de su envío, ni del tiempo y forma de su hipotética recepción".

${ }^{57} \mathrm{El}$ art.29.3 de la Ley de Marcas, ya citado en el Capítulo anterior cuando tratábamos de las notificaciones por fax, reza así: "Cuando el interesado así lo solicite, las notificaciones se realizarán mediante publicación en el Boletín Oficial de la Propiedad Industrial, mediante telefax, mediante correo electrónico, o por cualquier otro medio técnico del que disponga la Oficina Española de Patentes y Marcas". 
tadores de servicios electrónicos de comunicación. Si bien el precepto parece orientado a la persecución de delitos por parte de las fuerzas y cuerpos de seguridad del Estado ${ }^{58}$, su utilidad es evidente en punto a dejar constancia de un determinado intercambio telemático, al menos, para demostrar que un día y hora determinados se produjo el envío de un mensaje de correo electrónico desde una determinada dirección IP, y que tal otro día y hora se recibió en otra dirección IP determinada, lo cual es un indicio bastante robusto de la telecomunicación. De otro lado, para prevenir que este plazo de conservación finalice antes de la apertura del período probatorio -y se destruyan los datos-, el interesado en su conservación podría recabar del juez la petición del certificado al prestador del servicio como medida cautelar, con ocasión de la presentación de la demanda o del escrito de contestación.

De otro lado, la posibilidad de verificar pericialmente el origen IP de un determinado mensaje de correo electrónico evita, a mi juicio, la necesidad de que tales notificaciones se firmen digitalmente como garantía de identidad del emisor, contrariamente a lo que opina TORRES. ${ }^{59}$

\footnotetext{
${ }^{58} \mathrm{El}$ texto literal del art.12 LSSI es el siguiente: "1. Los operadores de redes y servicios de comunicaciones electrónicas, los proveedores de acceso a redes de telecomunicaciones y los prestadores de servicios de alojamiento de datos deberán retener los datos de conexión y tráfico generados por las comunicaciones establecidas durante la prestación de un servicio de la sociedad de la información por un período máximo de doce meses, en los términos establecidos en este artículo y en su normativa de desarrollo. 2. Los datos que, en cumplimiento de lo dispuesto en el apartado anterior, deberán conservar los operadores de redes y servicios de comunicaciones electrónicas y los proveedores de acceso a redes de telecomunicaciones serán únicamente los necesarios para facilitar la localización del equipo terminal empleado por el usuario para la transmisión de la información. Los prestadores de servicios de alojamiento de datos deberán retener sólo aquéllos imprescindibles para identificar el origen de los datos alojados y el momento en que se inició la prestación del servicio.(...) 3. Los datos se conservarán para su utilización en el marco de una investigación criminal o para la salvaguardia de la seguridad pública y la defensa nacional, poniéndose a disposición de los Jueces o Tribunales o del Ministerio Fiscal que así los requieran. La comunicación de estos datos a las Fuerzas y Cuerpos de Seguridad se hará con sujeción a lo dispuesto en la normativa sobre protección de datos personales. 4. Reglamentariamente, se determinarán las categorías de datos que deberán conservarse según el tipo de servicio prestado, el plazo durante el que deberán retenerse en cada supuesto dentro del máximo previsto en este artículo, las condiciones en que deberán almacenarse, tratarse y custodiarse y la forma en que, en su caso, deberán entregarse a los órganos autorizados para su solicitud y destruirse, transcurrido el plazo de retención que proceda, salvo que fueran necesarios para estos u otros fines previstos en la Ley".

${ }^{59}$ La autora entiende necesaria la firma electrónica en este tipo de mensajes para asegurar su autenticidad, vid. TORRES LÓPEZ, M.A.: "El documento...”, op.cit., págs.270 y sigs.
} 
En otro orden de consideraciones, la Administración del Estado ha establecido la posibilidad de que se cursen a los ciudadanos notificaciones de resoluciones de expedientes por correo electrónico, si bien a título meramente informativo ${ }^{60}$. Ahora bien, puede ocurrir que el ciudadano reciba esa notificación y por el contrario no llegue a recibir la postal. El tal caso, según las circunstancias que concurran, y con arreglo al régimen general dispuesto por el art.58.3 LRJAP, el acto notificado podría adquirir eficacia cuando el ciudadano realice actuaciones de las que se deduzca su conocimiento del contenido del acto, por ejemplo, interponiendo contra el mismo el recurso procedente. Nada hay que objetar, en este caso, a la notificación por correo electrónico realizada mediante cualquier servicio de mensajería electrónica, a pesar de que no reúna los rigurosos requisitos previstos por el art.59.3 LRJAP y los arts.12 y 15 DPAE.

\section{FINAL}

La mensajería electrónica supone una excelente herramienta para la notificación de los actos administrativos, habida cuenta que debido a los hábitos domésticos actuales los domicilios permanecen desocupados la mayor parte del tiempo haciendo difícilmente practicables las notificaciones postales, y teniendo en cuenta la cada vez mayor implantación del acceso a las tecnologías de la información y el conocimiento.

La LRJAP da entrada en esta materia al desarrollo reglamentario por parte de cada Administración pública de los requisitos técnicos relativos a este medio de notificación, abriendo espacio para la competencia normativa autonómica. La Junta de Andalucía la ha ejercido mediante el Decreto 183/2003, que contempla la cuestión, principalmente, en sus arts.12 y 15. En este trabajo hemos procurado solventar las dificultades de aplicación que muestran estos preceptos, y que vienen motivadas, fundamentalmente, por la defectuosa regulación de que la materia ha sido objeto en el Derecho común.

Ahora bien, para resolver definitivamente los problemas interpretativos que entraña el empleo de este medio de notificación por la Comunidad Au-

\footnotetext{
${ }^{60}$ A modo de ejemplo, en el portal del ciudadano existen muchos procedimientos que pueden iniciarse telemáticamente, ofreciéndose los impresos correspondientes; en ellos suele pedirse la dirección electrónica para notificaciones, especificando que se trata a efectos puramente informativos.
} 
tónoma, sería deseable que se dictara una disposición normativa subordinada (Orden de la Consejería de Justicia y Administración Pública, promovida por la Dirección General de la Administración Electrónica y Calidad de los Servicios, de la Secretaría General para la Administración Pública) que completara el régimen vigente. En este sentido, puede resultar un referente adecuado la Orden PRE/1551/2003, de 10 de junio, por tratarse de una de las pocas disposiciones generales que ha sido capaz de conciliar la calidad técnico-jurídica con los contenidos materiales de carácter tecnológico. Otra fuente de extraordinario valor son los Criterios de seguridad, normalización y conservación de las aplicaciones utilizadas para el ejercicio de potestades, aprobados por el Ministerio de Administraciones Públicas y periódicamente actualizados, que no se reducen a ser una orientación técnica en la adquisición o elaboración de aplicaciones informáticas, sino que pretenden convertirse en un cauce para "proporcionar el conjunto de medidas organizativas y técnicas de seguridad, normalización y conservación que garanticen el cumplimiento de los requisitos legales para la validez y eficacia de los procedimientos administrativos de la Administración General del Estado, que utilicen los medios electrónicos, informáticos y telemáticos en el ejercicio de potestades" ${ }^{\prime \prime}$.

La determinación de crear un Sistema de Notificaciones Telemáticas propio de Andalucía, denominado Notific@, es una decisión con luces y sombras. Por una parte, es acertada la opción de situar este servicio en la esfera pública, por dos circunstancias principales: el hecho de que los servidores convencionales de correo electrónico carecen por lo general del servicio añadido de sellado de fechas, que resulta imprescindible para la práctica de las notificaciones administrativas por correo electrónico; y la necesidad de que la Junta de Andalucía pueda dejar constancia de las incidencias de la notificación (notificaciones infructuosas, rechazo de la notificación...) lo que sólo se puede lograr cuando la propia Administración autonómica controla el servidor o bien ha suscrito con el prestador del servicio de mensajería un instrumento relacional (convenio o contrato) en el que se estipule la obligación de entregar certificaciones digitales de las incidencias de la notificación, a efectos de incorporarlas al expediente para satisfacer el requisito de constancia.

61 Cfr. pág. 6 del documento, accesible en http://www.csi.map.es/csi//(descargado el 8/9/04); existe versión impresa, publicada por el MAP, Madrid, 2004. La última versión impresa, publicada de este extenso documento (de más de 170 págs.), fue aprobada por el 2360 Pleno de la Comisión Interministerial de Adquisición de Bienes y Servicios Informáticos, celebrado el 24 de junio de 2004. 
Ahora bien, lo que ya no parece tan conveniente es el desarrollo de todo un sistema informático propio para soportar este servicio, cuando existe la posibilidad de suscribir un convenio de colaboración con Correos y Telégrafos análogo al que ya se ha firmado con la FNMT, a fin de que Andalucía pueda practicar sus notificaciones telemáticas a través del SNTS de la Administración del Estado. Por lo demás, la imposición en el Derecho propio de Andalucía del uso de la firma electrónica reconocida en las notificaciones por correo electrónico -lo que deriva del art.15 DPEA y viene corroborado por el sistema Notific@, que lo exige a los usuarios que quieran darse de alta- supone alcanzar unos estándares suficientemente robustos de seguridad, aunando garantías de autenticidad, integridad, confidencialidad y no rechazo o no repudio. Al encontrarse reconocido en Andalucía el certificado 2CA que facilita la FNMT, la disponibilidad de este requisito no supone coste alguno a los ciudadanos.

Tampoco parece acertado proceder a la implantación de este complejo sistema sin el apoyo de una disposición normativa de desarrollo que le preste cobertura, sobre todo cuando recordamos la existencia de problemas de integración entre diferentes preceptos del DPAE que hubiera convenido conciliar en un reglamento subordinado. Por ejemplo, la aparente libertad de opción del ciudadano por los medios telemáticos de notificación, que la implantación del sistema Notific@ constriñe a los concretos procedimientos incluidos en el propio sistema.

En cualquier caso, es de justicia reconocer la impecable factura técnica del sistema Notific@, que lo erige en un verdadero buque insignia de la Administración electrónica en Andalucía. Sólo el tiempo dirá si apuesta comprometida en su puesta en marcha se ve correspondida con la generalización del servicio. En mi opinión, sin embargo, y como me he cuidado de repetir a lo largo de todo el trabajo, sería mucho más provechosa la confluencia de todas las notificaciones telemáticas de las Administraciones públicas en un sistema único y común, para el que puede servir de soporte el SNTS de la Administración del Estado, cuya apertura a otras entidades del sector público -y especialmente a las dotadas de autonomía territorial- podría hacerse mediante su conversión en consorcio, lo que resultaría más respetuoso con el reparto competencial descrito por la LRJPAC en esta materia. La actual rigidez del sistema implantado por Correos y Telégrafos, que no opera sino con aplicaciones informáticas muy limitadas, impide avanzar en esta línea. Sería muy oportuno, pues, que todos los interlocutores implicados en este asunto reconsiderasen sus posiciones respectivas, ya que así se prestará un mejor servicio a los ciudadanos. 